\title{
Synthesis and Photophysical Studies of New Fluorescent Indole Derivatives Obtained from $\beta$-Bromodehydroamino Acids - Interaction with Fluoride Anions
}

\author{
Goreti Pereira, ${ }^{[a]}$ Elisabete M. S. Castanheira, ${ }^{*[b]}$ Paula M. T. Ferreira, ${ }^{*[a]}$ and \\ Maria-João R. P. Queiroz ${ }^{[a]}$
}

Keywords: Suzuki-Miyaura coupling / Metal-assisted cyclization / Indoles / Fluorescent probes / Fluorides / Nitrogen heterocycles / Cyclization

Several new indole derivatives were synthesised from $\beta$-brominated dehydroamino acids and arylboronic acids by using a strategy developed in our research group that involves a sequential Suzuki-Miyaura cross-coupling reaction and a metal-assisted C-N intramolecular cyclisation. The cyclised products were obtained either by direct cyclisation or by isomerisation followed by cyclisation. The photophysical properties of these compounds were studied in four solvents of different polarity (cyclohexane, diethyl ether, acetonitrile and ethanol). All these compounds have reasonably high fluorescence quantum yields (between 16 and 85\%) and show different solvent sensitivity in their fluorescence emission. These results indicate that the indole derivatives pre- pared are good candidates for fluorescent probes. The response of the new synthesised compounds towards fluoride ion $\left(\mathrm{F}^{-}\right)$was evaluated. It was found that methyl 3-methyl$1 H$-dibenzo[e,g]indole-2-carboxylate, methyl 3-(phenanthren-9-yl)-1H-dibenzo[e,g]indole-2-carboxylate and methyl 1-(naphthalen-1-yl)-3H-benzo[e]indole-2-carboxylate showed significant spectral changes in fluorescence emission upon $\mathrm{F}^{-}$addition with a decrease in intensity and the appearance of a new band at longer wavelengths. No detectable emission spectral changes were observed when several other anions were added to these compounds, which indicates their selectivity towards $\mathrm{F}^{-}$.

\section{Introduction}

In our laboratories, we have been interested in the synthesis of new fluorescent indole derivatives as fluorescent probes for peptides and proteins. These compounds were obtained from brominated dehydroamino acids and aryl- or heteroarylboronated compounds by using a Suzuki-Miyaura cross coupling followed by a metal-mediated $\mathrm{C}-\mathrm{N}$ intramolecular cyclisation developed in our research group. ${ }^{[1]}$ Recently, we have used this strategy to synthesise a phenalenoindole and a pyrenylindole from a $\beta$-bromodehydrophenylalanine or a $\beta$-bromodehydroaminobutyric acid and pyren-1-boronic acid, respectively. The fluorescence properties of these compounds in solution and in lipid membranes showed their potential as fluorescent probes for biological systems. ${ }^{[2]}$ In this work, we report the synthesis of several new compounds having the pyrrole unit fused with benzene, phenanthrene, 1,2-dihydroacenaphthylene and anthracene

[a] Centro de Química (CQ-UM), University of Minho,

Campus de Gualtar, 4710-057 Braga, Portugal

Fax: +351-253-604382

E-mail:pmf@quimica.uminho.pt

[b] Centro de Física (CFUM), University of Minho, Campus de Gualtar

4710-057 Braga, Portugal

Fax: +351-253-604061

E-mail: ecoutinho@fisica.uminho.pt

Supporting information for this article is available on the WWW under http://dx.doi.org/10.1002/ejoc.200900737. moieties to be studied as fluorescent probes and also to evaluate their behaviour in the presence of fluoride $\left(\mathrm{F}^{-}\right)$. Thus, several $\beta, \beta$-disubstituted dehydroamino acids were prepared in good to high yields from pure stereoisomers of a $\beta$-bromodehydroaminobutyric acid and a $\beta$ bromodehydrophenylalanine or a $\beta, \beta$-dibromodehydroalanine and arylboronic acids. These compounds were then treated with palladium and copper acetate to give the corresponding pyrrole-fused compounds. The photophysical properties of the latter were studied in several solvents. Since neutral $\mathrm{F}^{-}$sensors usually have hydrogen-bonding units such as pyrrole, urea, amide or phenol in their recognition sites, ${ }^{[3]}$ we decided to study the behaviour of the compounds prepared towards this anion. Due to the importance of $\mathrm{F}^{-}$in biology, medicine, food and environmental sciences, as it is a common ingredient in anaesthetics, hypnotics, psychiatric drugs, several poisons and is a contaminant in water, ${ }^{[4]}$ there is growing interest in the development of new molecules capable of selectively sensing $\mathrm{F}^{-}$in solution. These molecules contain a binding site that interacts with the anion and a signaling subunit with the ability of converting the binding event into a readable signal. ${ }^{[5]}$

\section{Results and Discussion}

We treated the pure stereoisomers of a $\beta$-bromodehydroaminobutyric acid $[(Z)$ - or $(E)-1]$ and a $\beta$-bromodehydro- 
phenylalanine $[(Z)-$ or $(E)-2]$ with 9-phenanthracenylboronic acid, (1,2-dihydroacenaphthylen-5-yl)boronic acid or 1-naphthylboronic acid under Suzuki-Miyaura coupling conditions to afford in good yields the corresponding $\beta$ substituted dehydroamino acids (Scheme 1). We determined the stereochemistry of these compounds using NOE difference experiments by irradiating the $\alpha-\mathrm{NH}$ and $\mathrm{OCH}_{3}$ protons. In the case of the $(Z)$ isomers, when we irradiated the $\mathrm{OCH}_{3}$ protons, we observed an NOE enhancement on the $\beta-\mathrm{CH}_{3}$ protons of dehydroaminobutyric acid derivatives or on the phenyl protons of dehydrophenylalanines. We confirmed the configuration of the $(E)$ isomers by the observation of a positive NOE of the $\beta-\mathrm{CH}_{3}$ or $\beta$-phenyl resonances when we irradiated the $\alpha-\mathrm{NH}$ group. As reported by other authors and us also, it was possible to correlate the chemical shifts of the $\mathrm{OCH}_{3}, \alpha-\mathrm{NH}$ and $\beta-\mathrm{CH}_{3}$ protons with the stereochemistry of the compounds. ${ }^{[6]}$ Thus, we observed the NMR chemical shifts of the $\mathrm{OCH}_{3}$ and $\beta-\mathrm{CH}_{3}$ protons of the $(Z)$ isomers of the dehydroaminobutyric acid derivatives at lower fields than those of the $(E)$ isomers (Table 1). We also found this relation in the case of the $\mathrm{OCH}_{3}$ protons of dehydrophenylalanines (Table 1). The $\alpha$ $\mathrm{NH}$ resonances of all the $(Z)$ isomers of $\beta$-aryldehydroaminobutyric acids and dehydrophenylalanines appeared at higher field than those of the $(E)$ isomers. This is probably due to the shielding anisotropic effect of the aryl moiety.

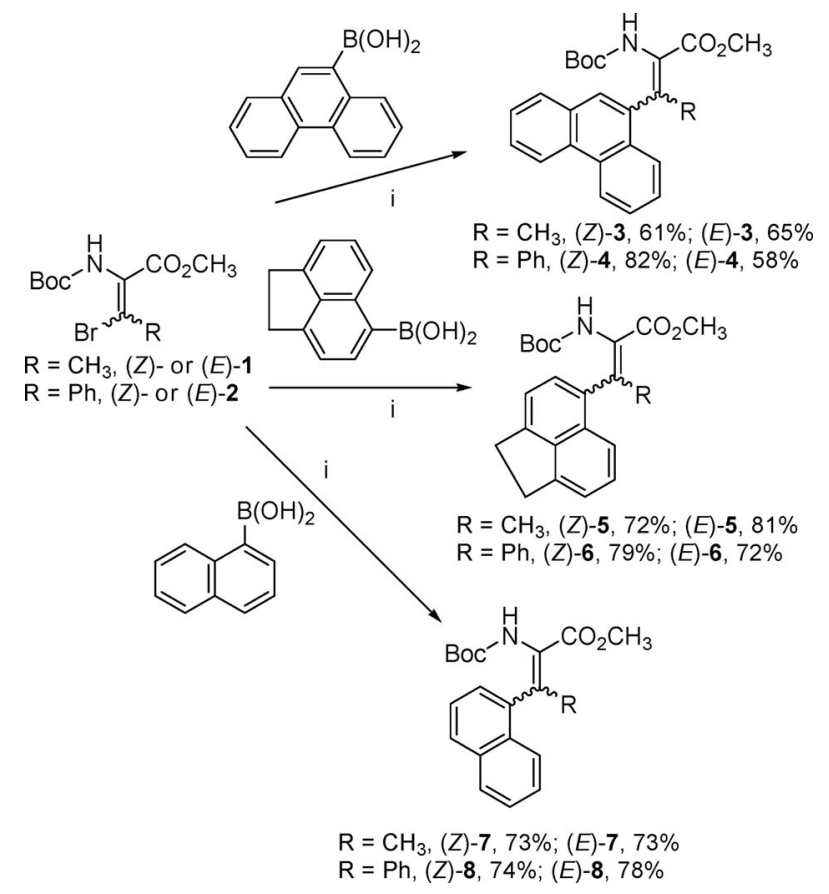

Scheme 1. Synthesis of $\beta$-aryldehydroaminobutyric acid and dehydrophenylalanine derivatives. (i) $\mathrm{PdCl}_{2} \mathrm{dppf} \cdot \mathrm{CH}_{2} \mathrm{Cl}_{2}$ (1:1) (10 mol$\%) ; \mathrm{Cs}_{2} \mathrm{CO}_{3}$ (1.4 equiv.); THF/ $\mathrm{H}_{2} \mathrm{O}(1: 1)$.

When we used $\beta, \beta$-dibromodehydroalanine $(9)^{[1]}$ as a substrate, we obtained the corresponding disubstituted dehydroalanines 10-12 in good yields (between 63 and 71\%, Scheme 2).
Table 1. ${ }^{1} \mathrm{H}$ NMR chemical shifts of $\beta$-aryldehydroaminobutyric acid and dehydrophenylalanine derivatives in $\mathrm{CDCl}_{3}$ $\left(5 \times 10^{-3} \mathrm{~mol} \mathrm{dm}^{-3}\right)$.

\begin{tabular}{ccccc}
\hline Entry & Compound & \multicolumn{3}{c}{$\delta[\mathrm{ppm}]$} \\
& & $\alpha-\mathrm{NH}$ & $\begin{array}{c}\mathrm{OCH}_{3} \\
\beta-\mathrm{CH}_{3}\end{array}$ \\
\hline 1 & $(Z)-\mathbf{3}$ & 5.61 & 3.95 & 2.38 \\
2 & $(E)-\mathbf{3}$ & 6.28 & 3.24 & 2.27 \\
3 & $(Z)-\mathbf{4}$ & 5.77 & 3.70 & - \\
4 & $(E)-\mathbf{4}$ & 6.42 & 3.23 & - \\
5 & $(Z)-5$ & 5.56 & 3.91 & 2.32 \\
6 & $(E)-\mathbf{5}$ & 6.16 & 3.30 & 2.23 \\
7 & $(Z)-6$ & 5.76 & 3.64 & - \\
8 & $(E)-6$ & 6.31 & 3.33 & - \\
9 & $(Z)-7$ & 5.48 & 3.92 & 2.32 \\
10 & $(E)-7$ & 6.22 & 3.25 & 2.24 \\
11 & $(Z)-8$ & 5.67 & 3.66 & - \\
12 & $(E)-8$ & 6.35 & 3.23 & - \\
\hline
\end{tabular}

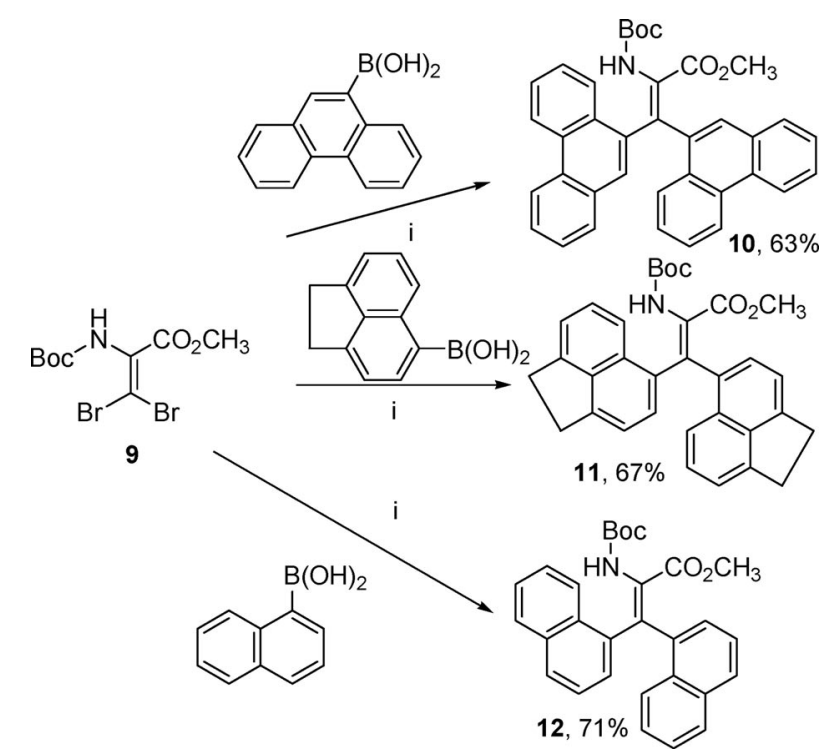

Scheme 2. Synthesis of $\beta, \beta$-diaryldehydroalanine derivatives. (i) $\mathrm{PdCl}_{2} \mathrm{dppf} \cdot \mathrm{CH}_{2} \mathrm{Cl}_{2}$ (1:1) (10 mol-\%); $\mathrm{Cs}_{2} \mathrm{CO}_{3}$ (1.4 equiv.); THF/ $\mathrm{H}_{2} \mathrm{O}(1: 1)$.

We then submitted some of these disubstituted dehydroamino acid derivatives (3-12) to a $\mathrm{Pd} / \mathrm{Cu}$-assisted $\mathrm{C}-\mathrm{N}$ intramolecular cyclisation to afford the corresponding indole derivatives (Table 2). This reaction involved the electrophilic attack of $\mathrm{Pd}^{\mathrm{II}}$ on the aromatic ring and a nucleophilic attack of $\mathrm{N}$, forming a palladacycle. ${ }^{[1]}$ The only products isolated from the cyclisation of (Z)-4 and (Z)-8 resulted from isomerisation followed by cyclisation giving $\mathbf{1 4}$ and 20, respectively. Compounds $(E)-\mathbf{4}$ and $(E)-\mathbf{8}$ gave $\mathbf{1 4}$ and $\mathbf{2 0}$ in similar yields to those obtained by using (Z)-4 and (Z)-8 as starting materials. In the case of (Z)-6, although the major product $(\mathbf{1 7}, 52 \%)$ resulted from isomerisation followed by cyclisation, we also isolated $18(13 \%)$ resulting from a direct cyclisation. In this case, the cyclisation of $(E)-\mathbf{6}$ afforded the same ratio of $\mathbf{1 7}$ and $\mathbf{1 8 .}$

Jones and Mathews ${ }^{[7]}$ synthesised compounds similar to 15 with a $1 H$-dibenzo[e,g]indole moiety. The synthesis involved the formylation of a 9-bromophenanthrene followed 
Table 2. Yields of the cyclisation products and ${ }^{1} \mathrm{H}$ NMR chemical shifts of the NH signals in $\left[\mathrm{D}_{6}\right] \mathrm{DMSO}\left(5 \times 10^{-3} \mathrm{moldm}^{-3}\right)$.
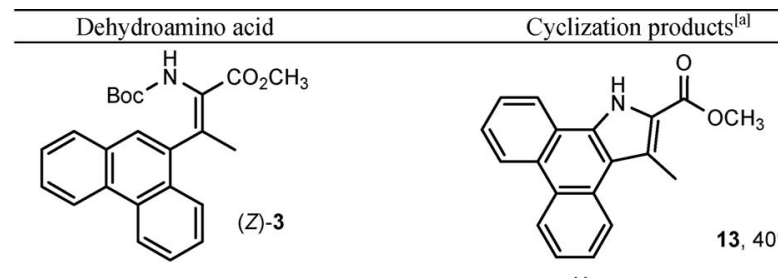<smiles>CC(=O)NC(C(C)=O)=C(c1ccccc1)c1cc2ccccc2c2ccccc12</smiles><smiles>COC(=O)c1[nH]c2ccccc2c1-c1cc2ccccc2c2ccccc12</smiles>

12.403<smiles>CC(=O)OC(C)(C)OC(=O)C(=C(c1cc2ccccc2c2ccccc12)c1cc2ccccc2c2ccccc12)C(C)(C)C</smiles><smiles>COC(=O)c1[nH]c2c3ccccc3c3ccccc3c2c1-c1cc2ccccc2c2ccccc12</smiles><smiles>CC(=O)OC(C)=C(NC(=O)OCc1ccccc1)c1ccc2c3c(cccc13)CC2</smiles><smiles>COC(=O)c1[nH]c2cc3c4c(cccc4c2c1C)CC3</smiles><smiles>CC(=O)OC(=O)C(NC(=O)c1ccccc1)=C(c1ccccc1)c1ccc2c3c(cccc13)CC2</smiles><smiles>COC(=O)c1[nH]c2ccccc2c1-c1ccc2c3c(cccc13)CC2</smiles><smiles>COC(=O)c1[nH]c2cc3c4c(cccc4c2c1-c1ccccc1)CC3</smiles><smiles>CC(=O)C(NC(=O)OCc1ccccc1)=C(C)c1cccc2ccccc12</smiles><smiles>COC(=O)c1[nH]c2ccc3ccccc3c2c1C</smiles><smiles>CC(=O)OC(C)(C)OC(=O)NC(C(=O)NC(C)(C)C)=C(c1ccccc1)c1cccc2ccccc12</smiles><smiles>COC(=O)c1[nH]c2ccccc2c1-c1cccc2ccccc12</smiles><smiles>CC(=O)OC(=O)C(NC(=O)OCc1ccccc1)=C(c1cccc2ccccc12)c1cccc2ccccc12</smiles><smiles>COC(=O)c1[nH]c2ccc3ccccc3c2c1-c1cccc2ccccc12</smiles>

12.029

12.595

[a] Cyclisation conditions: $\mathrm{Pd}(\mathrm{OAc})_{2}(50 \mathrm{~mol}-\%), \mathrm{Cu}(\mathrm{OAc})_{2} \cdot \mathrm{H}_{2} \mathrm{O}$ (3 equiv.), DMF, $160^{\circ} \mathrm{C}, 3-4 \mathrm{~h}$.

by the transformation of the aldehyde into an azidocinnamate using a Rees-Moody protocol. The latter gave the methyl $1 H$-dibenzo[e,g]indole-2-carboxylate by thermolysis.
We studied the absorption and fluorescence properties of 13-21 in four solvents of different polarity (cyclohexane, diethyl ether, acetonitrile and ethanol). The maximum ab- 
sorption $\left(\lambda_{\text {abs }}\right)$ and emission wavelengths $\left(\lambda_{\mathrm{em}}\right)$, molar absorption coefficients $(\varepsilon)$ and fluorescence quantum yields $\left(\Phi_{\mathrm{F}}\right)$ of these indole derivatives are presented in Tables 3 and 4 . The normalised absorption and fluorescence spectra of 13-21 are presented in Figures 1,2 and 3.

All indole derivatives 13-21 presented relatively high molar absorption coefficients at the lowest energy maximum $(\varepsilon$ $\geq 5.3 \times 10^{3} \mathrm{M}^{-1} \mathrm{~cm}^{-1}$ ) in all the solvents studied (Tables 3 and 4). The near-UV absorption of indole and its derivatives was attributed to two strongly overlapping $\pi \rightarrow \pi^{*}$ transitions, ${ }^{[9-11]}$ with an average $\varepsilon$ value for unsubstituted indole of $5500 \mathrm{M}^{-1} \mathrm{~cm}^{-1}$. ${ }^{12]} \mathrm{A}$ methyl carboxylate group is present in our compounds, and it is known that many carbonyl compounds present a low-lying $n \rightarrow \pi^{*}$ state. The $\pi \rightarrow \pi^{*}$ and $n \rightarrow \pi^{*}$ electronic transitions can also be nearby in energy, resulting in state mixing. ${ }^{[13]}$ The higher $\varepsilon$ values observed here can be explained by a predominance of $\pi \rightarrow \pi^{*}$ character in these compounds (Tables 3 and 4).

The absorption spectra of the indole derivatives 14, 17 and $\mathbf{2 0}$ presented a broad and unstructured lowest-energy band, due to the strong conjugation of the indole moiety with the adjacent aromatic rings. A similar behaviour has

Table 3. Maximum absorption $\left(\lambda_{\mathrm{abs}}\right)$ and emission $\left(\lambda_{\mathrm{em}}\right)$ wavelengths, molar absorption coefficients $(\varepsilon)$ and fluorescence quantum yields $\left(\Phi_{\mathrm{F}}\right)$ for 13-16.

\begin{tabular}{|c|c|c|c|c|c|c|c|c|c|c|c|c|}
\hline \multirow{2}{*}{ Solvent } & \multicolumn{4}{|c|}{$\lambda_{\text {abs }}[\mathrm{nm}]\left(\varepsilon\left[10^{4} \mathrm{M}^{-1} \mathrm{~cm}^{-1}\right]\right)$} & \multicolumn{4}{|c|}{$\lambda_{\mathrm{em}}[\mathrm{nm}]$} & \multicolumn{4}{|c|}{$\Phi_{\mathrm{F}}^{[a]}$} \\
\hline & 13 & 14 & 15 & 16 & 13 & 14 & 15 & 16 & 13 & 14 & 15 & 16 \\
\hline Cyclohexane & $\begin{array}{l}357(0.53), \\
340(0.49), \\
321(1.44), \\
305(1.32) \\
266(4.46)\end{array}$ & $\begin{array}{l}298(2.47) \\
249(6.27) \\
226(5.14) \\
211(5.50)\end{array}$ & $\begin{array}{l}355(0.75), \\
338(0.75), \\
321(1.66), \\
300(2.36), \\
256(8.36)\end{array}$ & $\begin{array}{l}352(2.34) \\
335(1.56) \\
318(1.38) \\
273(2.00) \\
238(2.71)\end{array}$ & $\begin{array}{l}359 \\
377 \\
398\end{array}$ & 399 & $\begin{array}{l}357 \\
375 \\
396, \\
416\end{array}$ & $\begin{array}{l}353 \\
359 \\
372 \\
392\end{array}$ & 0.44 & 0.70 & 0.42 & 0.61 \\
\hline Diethyl ether & $\begin{array}{l}357(0.55), \\
340(0.51), \\
319(1.52), \\
305(1.43), \\
265(4.68)\end{array}$ & $\begin{array}{l}297(2.71) \\
250(6.62) \\
226(6.58)\end{array}$ & $\begin{array}{l}354(0.76), \\
338(0.75), \\
319(1.68), \\
299(2.31), \\
255(7.87)\end{array}$ & $\begin{array}{l}352(2.37), \\
335(1.64), \\
319(1.39), \\
274(2.31), \\
239(2.63)\end{array}$ & $\begin{array}{l}357 \\
376 \\
396\end{array}$ & 396 & $\begin{array}{l}356, \\
374 \\
395 \\
414\end{array}$ & $\begin{array}{l}353 \\
371 \\
391\end{array}$ & 0.4 & 0.68 & 0.37 & 0.56 \\
\hline Acetonitrile & $\begin{array}{l}355(0.59), \\
338(0.60), \\
318(1.54), \\
303(1.53), \\
265(4.79)\end{array}$ & $\begin{array}{l}297(2.25) \\
248(5.88) \\
226(4.64), \\
211(4.89)\end{array}$ & $\begin{array}{l}354(0.67), \\
337(0.68), \\
317(1.62), \\
300(2.26), \\
255(7.82)\end{array}$ & $\begin{array}{l}351(2.17) \\
335(1.56) \\
318(1.39) \\
273(2.22), \\
238(2.93)\end{array}$ & $\begin{array}{l}361 \\
377 \\
395\end{array}$ & 401 & $\begin{array}{l}358 \\
375 \\
394\end{array}$ & $\begin{array}{l}356 \\
374 \\
392\end{array}$ & 0.36 & 0.55 & 0.16 & 0.59 \\
\hline Ethanol & $\begin{array}{l}357(0.62), \\
340(0.59), \\
320(1.42), \\
305(1.34), \\
265(4.28)\end{array}$ & $\begin{array}{l}298(2.47) \\
249(6.26) \\
227(4.84) \\
210(5.31)\end{array}$ & $\begin{array}{l}355(0.91), \\
338(0.87), \\
320(1.59), \\
300(2.17), \\
256(7.49)\end{array}$ & $\begin{array}{l}352(2.19), \\
336(1.61), \\
320(1.43), \\
275(2.38), \\
239(2.94)\end{array}$ & $\begin{array}{l}361, \\
378 \\
398\end{array}$ & 417 & $\begin{array}{l}357 \\
376 \\
395\end{array}$ & $\begin{array}{l}362 \\
378\end{array}$ & 0.41 & 0.57 & 0.24 & 0.54 \\
\hline
\end{tabular}

[a] Relative to 9,10-diphenylanthracene in ethanol $\left(\Phi=0.95\right.$ at $\left.25^{\circ} \mathrm{C}\right) .{ }^{[8]}$ The error was approximately $10 \%$. Diethyl ether cut-off: $215 \mathrm{~nm}$.

Table 4. Maximum absorption $\left(\lambda_{\mathrm{abs}}\right)$ and emission $\left(\lambda_{\mathrm{em}}\right)$ wavelengths, molar absorption coefficients $(\varepsilon)$ and fluorescence quantum yields $\left(\Phi_{\mathrm{F}}\right)$ for 17-21.

\begin{tabular}{|c|c|c|c|c|c|c|c|c|c|c|c|c|c|c|c|}
\hline \multirow{2}{*}{ Solvent } & \multicolumn{5}{|c|}{$\lambda_{\text {abs }}[\mathrm{nm}]\left(\varepsilon\left[10^{4} \mathrm{M}^{-1} \mathrm{~cm}^{-1}\right]\right)$} & \multicolumn{5}{|c|}{$\lambda_{\mathrm{em}}[\mathrm{nm}]$} & \multicolumn{5}{|c|}{$\Phi_{\mathrm{F}}^{[\mathrm{a}]}$} \\
\hline & 17 & 18 & 19 & 20 & 21 & 17 & 18 & 19 & 20 & 21 & 17 & 18 & 19 & 20 & 21 \\
\hline Cyclohexane & $\begin{array}{l}294(2.06) \\
224(6.21)\end{array}$ & $\begin{array}{l}352(1.82), \\
336(1.29), \\
316(1.03), \\
374(1.56), \\
237(1.87), \\
223(2.18)\end{array}$ & $\begin{array}{l}345(1.13), \\
322(1.58), \\
308(1.82), \\
270(1.77), \\
233(3.11)\end{array}$ & $\begin{array}{l}291(1.73), \\
219(7.20)\end{array}$ & $\begin{array}{l}344(1.09), \\
328(1.24), \\
304(1.59), \\
283(1.68), \\
223(8.11)\end{array}$ & 399 & $\begin{array}{l}355 \\
373 \\
393\end{array}$ & $\begin{array}{l}346, \\
364, \\
382\end{array}$ & 393 & $\begin{array}{l}347 \\
364 \\
383\end{array}$ & 0.53 & 0.85 & 0.59 & 0.60 & 0.72 \\
\hline Diethyl ether & $\begin{array}{l}295(1.99) \\
224(5.75)\end{array}$ & $\begin{array}{l}351(2.06), \\
335(1.53), \\
317(1.27), \\
276(2.49), \\
238(3.06), \\
224(4.17)\end{array}$ & $\begin{array}{l}345(1.18), \\
329(1.71), \\
310(1.89), \\
271(2.24), \\
234(3.03)\end{array}$ & $\begin{array}{l}293(1.67) \\
220(6.28)\end{array}$ & $\begin{array}{l}344(1.11), \\
328(1.33), \\
308(1.57) \\
274(1.84), \\
222(7.73)\end{array}$ & 401 & $\begin{array}{l}356 \\
374 \\
392\end{array}$ & $\begin{array}{l}346, \\
364, \\
381\end{array}$ & 394 & $\begin{array}{l}347 \\
364 \\
382\end{array}$ & 0.64 & 0.53 & 0.74 & 0.61 & 0.54 \\
\hline Acetonitrile & $\begin{array}{l}296(1.87) \\
224(5.92)\end{array}$ & $\begin{array}{l}351(1.76), \\
335(1.35), \\
317(1.14), \\
275(2.06), \\
237(2.45), \\
222(2.98)\end{array}$ & $\begin{array}{l}343(1.10), \\
327(1.66), \\
310(1.83), \\
270(2.22), \\
233(3.34)\end{array}$ & $\begin{array}{l}293(1.44) \\
220(6.04)\end{array}$ & $\begin{array}{l}343(1.04), \\
327(1.29), \\
308(1.48), \\
275(1.84), \\
222(7.66)\end{array}$ & 426 & $\begin{array}{l}364 \\
376\end{array}$ & $\begin{array}{l}349, \\
366, \\
383\end{array}$ & 396 & $\begin{array}{l}351 \\
366\end{array}$ & 0.70 & 0.64 & 0.48 & 0.71 & 0.39 \\
\hline Ethanol & $\begin{array}{l}297(2.04), \\
224(6.29)\end{array}$ & $\begin{array}{l}353(1.53), \\
337(1.18), \\
319(1.00), \\
378(1.80), \\
238(1.96), \\
223(2.23)\end{array}$ & $\begin{array}{l}345(1.06), \\
329(1.64), \\
313(1.68), \\
273(2.10), \\
234(3.00)\end{array}$ & $\begin{array}{l}294(1.68) \\
219(6.99)\end{array}$ & $\begin{array}{l}344(1.30), \\
328(1.60), \\
311(1.78), \\
276(2.29), \\
222(9.12)\end{array}$ & 443 & 382 & $\begin{array}{l}354, \\
369\end{array}$ & 411 & $\begin{array}{l}357 \\
371\end{array}$ & 0.54 & 0.43 & 0.51 & 0.78 & 0.51 \\
\hline
\end{tabular}

[a] Relative to 9, 10 -diphenylanthracene in ethanol $\left(\Phi=0.95\right.$ at $\left.25^{\circ} \mathrm{C}\right) .{ }^{[8]}$ The error was approximately $10 \%$. Diethyl ether cut-off: $215 \mathrm{~nm}$. 


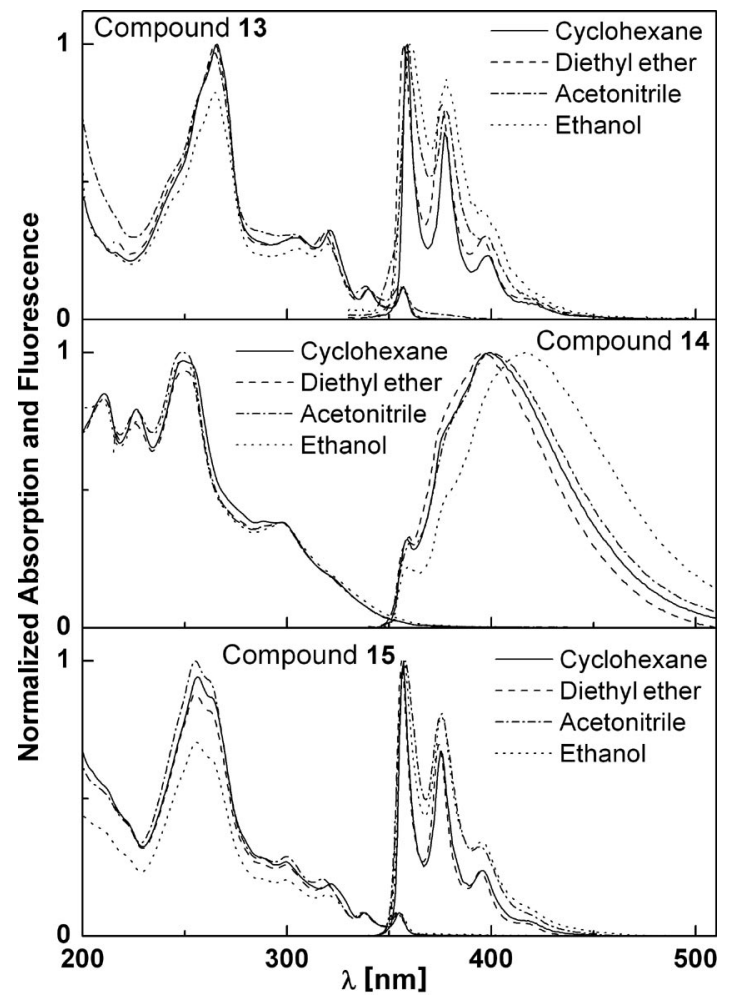

Figure 1. Normalised absorption (in the lowest energy peak) and fluorescence spectra of solutions $\left(2 \times 10^{-5} \mathrm{M}\right.$ for absorption and $2 \times 10^{-6} \mathrm{M}$ for fluorescence) of $\mathbf{1 3 - 1 5}$, in several solvents.

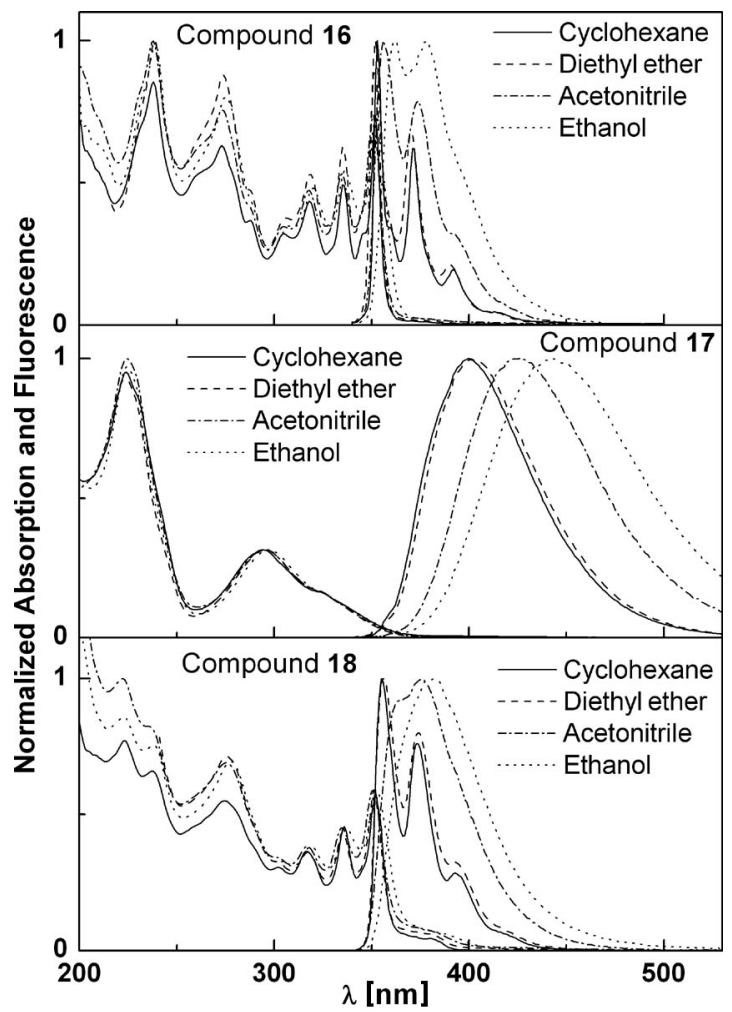

Figure 2. Normalised absorption (in the lowest energy peak) and fluorescence spectra of solutions $\left(2 \times 10^{-5} \mathrm{M}\right.$ for absorption and $2 \times 10^{-6} \mathrm{M}$ for fluorescence) of $\mathbf{1 6 - 1 8}$, in several solvents.

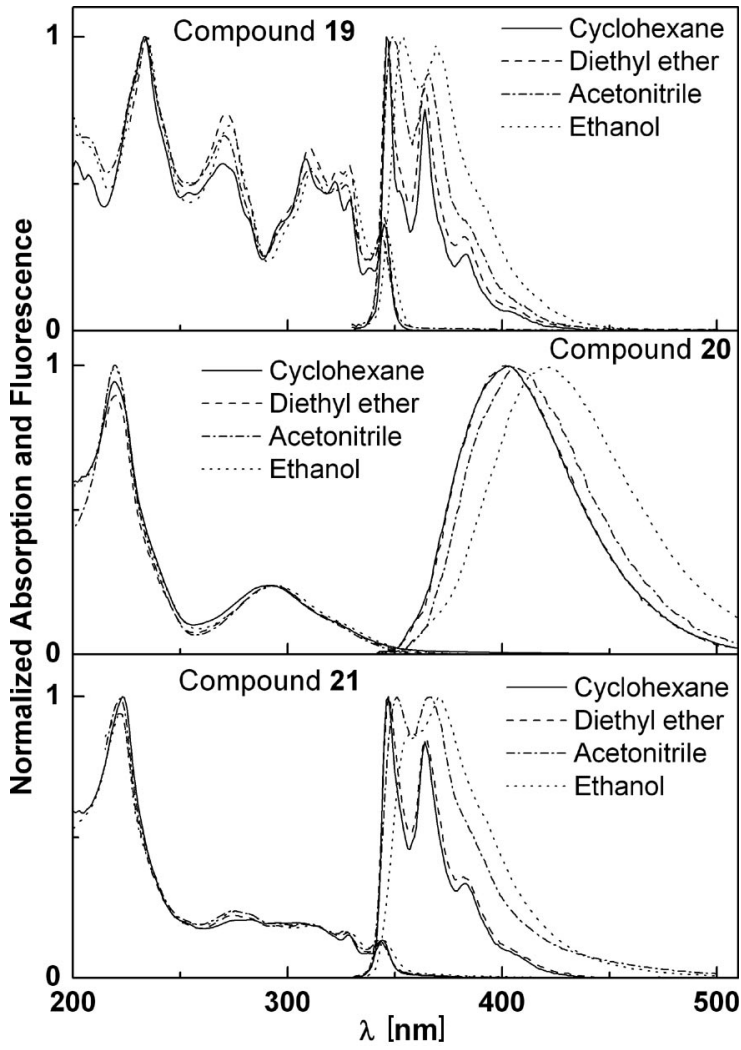

Figure 3. Normalised absorption (in the lowest energy peak) and fluorescence spectra of solutions $\left(2 \times 10^{-5} \mathrm{M}\right.$ for absorption and $2 \times 10^{-6} \mathrm{M}$ for fluorescence) of 19-21, in several solvents.

previously been observed in a pyrenylindole-2-carboxylate compound.$^{[2]}$ All other compounds, which had the indole moiety condensed in an extended aromatic system, presented a structured absorption spectrum in the lower-energy region, as observed for a phenalenoindole ${ }^{[2]}$ and pyrene[2,1-b]pyrrole derivatives. ${ }^{[14]}$

The fluorescence spectra of indoles $\mathbf{1 4}, \mathbf{1 7}$ and $\mathbf{2 0}$ were mainly unstructured bands, with large Stokes' shifts and appreciable solvatochromic behaviour, typical of the chargetransfer (CT) character of the excited state, even in nonpolar solvents. The influence of the solvent on the absorption spectral shape was negligible. The effect on the emission spectra was more pronounced for $\mathbf{1 7}$, where the spectral shift between cyclohexane and ethanol was $44 \mathrm{~nm}$. We observed a similar behaviour due to a high CT character of the excited state for a pyrenylindole-2-carboxylate. ${ }^{[2]} \mathrm{Com}-$ pound 14 exhibited a slightly structured emission and a small peak on the higher-energy side (at $359 \mathrm{~nm}$ ), indicating that there was a small contribution from the locally excited (LE) state.

All the other compounds (13, 15, 16, 18, 19 and 21), displayed fluorescence spectra with well-defined vibrational structure, especially in solvents of low polarity (Figures 1, 2 and 3). Compounds $\mathbf{1 3}$ and $\mathbf{1 5}$ had similar absorption and fluorescence spectra (Figure 1), with a low influence of the solvent on the emission spectra. This behaviour indicates that the substituent attached to the dibenzo[e,g]indole-2- 
carboxylate moiety (a methyl group in $\mathbf{1 3}$ and a phenanthracenyl group in 15) had a small contribution to the lowest excited state.

We observed a pronounced loss of vibrational structure in polar solvents for $\mathbf{1 8}$ and $\mathbf{2 1}$ (Figures 2 and 3), indicating the CT character of the excited state in polar solvents. The effect was more significant in ethanol, probably due to contribution of hydrogen bonding from this protic solvent, through the $\alpha-\mathrm{NH}$ group (donor) or carboxylate group (acceptor). The extension of the conjugation by the substitution of a methyl group (16 and 19) by an aromatic moiety (18 and 21, respectively) provides a significant increase in excited-state CT character.

All compounds had reasonable to high fluorescence quantum yields in almost all the solvents studied (Tables 3 and 4), attaining $70-80 \%$ in some cases. We observed the lowest $\Phi_{\mathrm{F}}$ values (between 16 and $42 \%$ ) for $\mathbf{1 5}$, which is the largest molecule with seven aromatic rings and showed a predominance of the nonradiative pathways of deactivation. The generally high fluorescence quantum yields of these new indole derivatives and the different solvent sensitivity of their fluorescence emission make them good candidates for fluorescent probes.

It has been established that compounds containing pyrrole, urea, amide, amine or phenol units can act as $\mathrm{F}^{-}$sensors. ${ }^{[3]}$ We also evaluated the response of 13-21 toward $\mathrm{F}^{-}$ ions. We performed fluorescence titration experiments on $5 \times 10^{-6} \mathrm{M}$ solutions in acetonitrile with the incremental addition of $\mathrm{F}^{-}$(as the tetrabutylammonium salt). We observed significant spectral changes in emission upon $\mathrm{F}^{-}$addition for 13, 15 and 21 (Figures 4, 5 and 6), especially for $\mathbf{1 3}$ and 15. The emission spectrum of each compound decreased in intensity, and a new unstructured band appeared at longer wavelengths (maximum at ca. $465 \mathrm{~nm}$ for $\mathbf{1 3}, 515 \mathrm{~nm}$ for $\mathbf{1 5}$ and ca. $510 \mathrm{~nm}$ for 21). In all cases, we observed a clear isoemissive point [at $423 \mathrm{~nm}$ for $\mathbf{1 3}$ (Figure 4), $432 \mathrm{~nm}$ for $\mathbf{1 5}$ (Figure 5) and $440 \mathrm{~nm}$ for 21 (Figure 6)]. Compounds $\mathbf{1 3}$

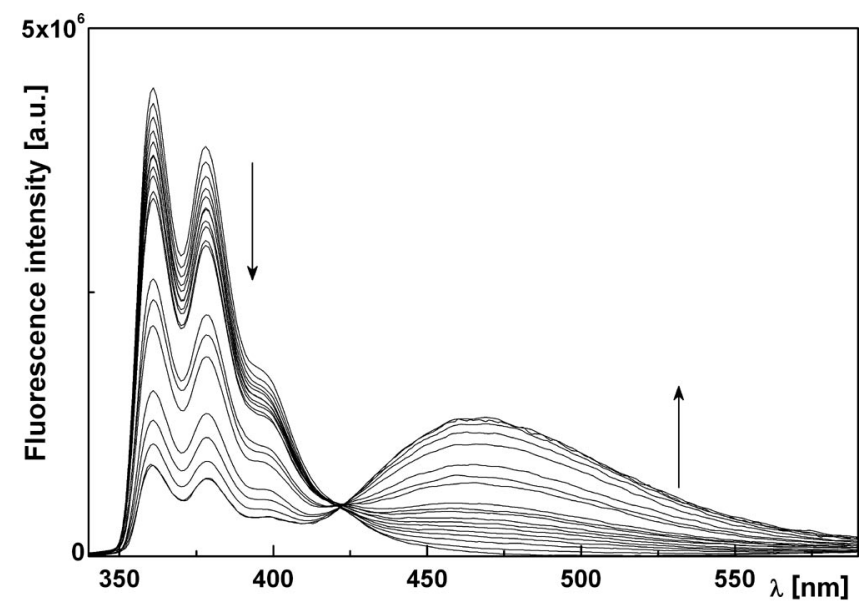

Figure 4. Fluorescence emission spectra $\left(\lambda_{\mathrm{ex}}=325 \mathrm{~nm}\right)$ of $\mathbf{1 3}$ $\left(5 \times 10^{-6} \mathrm{M}\right.$ in acetonitrile) in the presence of different amounts of $\mathrm{F}^{-}(0,10,20,30,40,50,60,70,80,90,100,150,200,250,300$, $350,400,450$ and 500 equiv.). and $\mathbf{1 5}$ exhibited noticeable spectral changes at intervals of 10 and 5 equiv. of $\mathrm{F}^{-}$, respectively (Figures 4 and 5), whereas for 21, the spectral changes were significantly smaller (Figure 6). The addition of $\mathrm{F}^{-}$to solutions of $\mathbf{1 3}$ and $\mathbf{1 5}$ led to an intensely coloured fluorescence (blue and green, respectively) upon irradiation with near-UV light (see the Supporting Information).

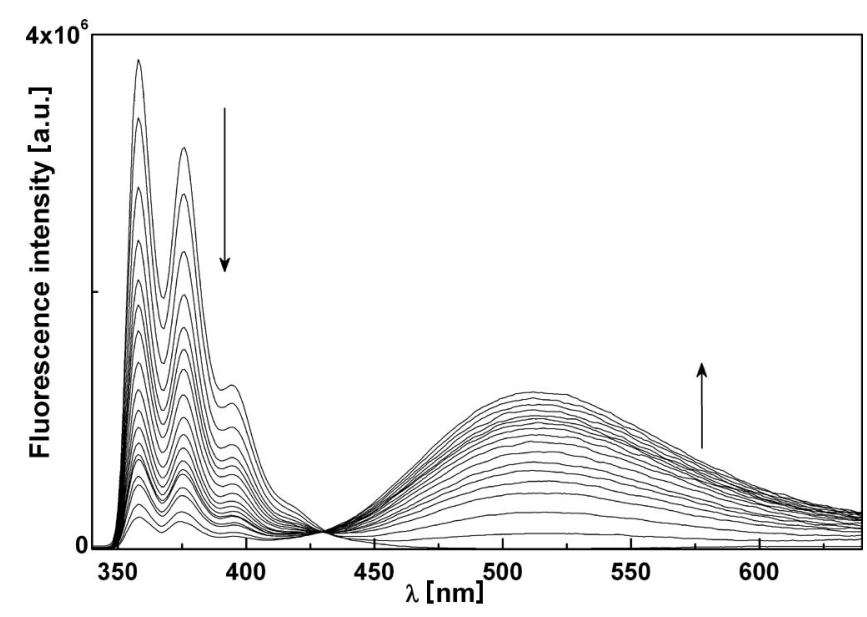

Figure 5. Fluorescence emission spectra $\left(\lambda_{\mathrm{ex}}=335 \mathrm{~nm}\right)$ of $\mathbf{1 5}$ $\left(5 \times 10^{-6} \mathrm{M}\right.$ in acetonitrile) in the presence of different amounts of $\mathrm{F}^{-}(0,5,10,15,20,25,30,40,50,60,70,80,90,100,130,150$, 200 and 250 equiv.).

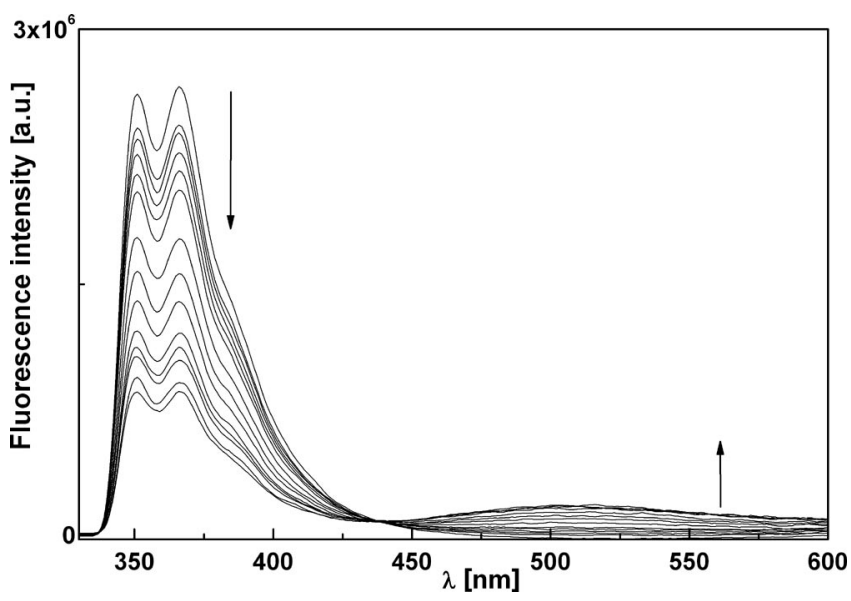

Figure 6. Fluorescence emission spectra $\left(\lambda_{\mathrm{ex}}=325 \mathrm{~nm}\right)$ of 21 $\left(5 \times 10^{-6} \mathrm{M}\right.$ in acetonitrile) in the presence of different amounts of $\mathrm{F}^{-}(0,20,40,60,80,100,150,200,250,300,350,400,450$ and 500 equiv.).

The corresponding UV/Vis absorption titrations caused smaller spectral changes, but we observed clear changes for larger amounts of $\mathrm{F}^{-}$, with the appearance of a new band in the higher-wavelength region of the absorption spectrum (see the Supporting Information). The excitation spectrum obtained at the compound emission region was always very 
similar to the absorption spectrum in the absence of $\mathrm{F}^{-}$. The excitation spectrum recorded at the maximum of the new fluorescence band (where the compound emission is negligible) also resembled the absorption spectrum (for the same $\mathrm{F}^{-}$content), considering that the latter has a contribution from the pure compound absorption (see the Supporting Information).

We observed no detectable emission spectral changes with $\mathrm{F}^{-}$addition to indoles 14, 16-18 and 20. For 19, we detected a small new emission band in the presence of $\mathrm{F}^{-}$, but only with large amounts of the anion ( $\geq 300$ equiv.), and changes with further increases of $\mathrm{F}^{-}$content were negligible.

The ${ }^{1} \mathrm{H}$ NMR spectra in $\left[\mathrm{D}_{6}\right] \mathrm{DMSO}$ of $\mathbf{1 3}$ and $\mathbf{1 5}$ showed the appearance of a triplet at $\delta \approx 16 \mathrm{ppm}$, characteristic of the FHF moiety formed upon the addition of 2 equiv. of $\mathrm{F}^{-} \cdot{ }^{[15]}$ This clearly shows that the mechanism of $\mathrm{F}^{-}$recognition was the deprotonation of the indole group by the $\mathrm{F}^{-}$ion in the ground state. This explains why in these new compounds the $\mathrm{F}^{-}$recognition is stronger for compounds with a higher NH chemical shift $(\mathbf{1 3}, 15$ and 21; see Table 2). The higher NH acidity in these three compounds can facilitate the hydrogen abstraction process and the formation of the FHF species.

The formation of a compound anion also justifies the anomalously large spectral shifts between the compound emission (first peak) and the new fluorescence band ${ }^{[16]}$ (104 nm for 13, $157 \mathrm{~nm}$ for $\mathbf{1 5}$ and $159 \mathrm{~nm}$ for 21). The fluorescence titration of a solution of $\mathbf{1 5}$ with $\mathrm{OH}^{-}$in acetonitrile revealed similar spectral changes as those observed with $\mathrm{F}^{-}$(see the Supporting Information), with the new unstructured band arising at the same emission wavelengths (maximum at $515 \mathrm{~nm}$ ), indicating that this new emission is due to an indole $\mathbf{1 5}$ anion. The absorption spectra in the presence of $\mathrm{OH}^{-}$and $\mathrm{F}^{-}$were also roughly similar (see the Supporting Information), pointing to the formation of identical species in the ground state, in the presence of either of the two anions. A similar behaviour was reported for the pyreno[2,1-b]pyrrole interaction with $\mathrm{F}^{-}$and $\mathrm{OH}^{-}$in acetonitrile. ${ }^{[16]}$ Intermolecular excited-state proton-transfer processes have been reported in several indoles, with strong hydrogen bonding with polar solvent molecules leading to ion-pair formation. ${ }^{[17]}$ However, in our new indole derivatives, the proton abstraction from the $\mathrm{NH}$ group occurred in the ground state (for an $\mathrm{F}^{-}$amount above 2 equiv.).

To examine the $\mathrm{F}^{-}$selectivity of these compounds, we performed fluorescence titrations of solutions of 13,15 and 21 in acetonitrile with various anions $\left(\mathrm{Cl}^{-}, \mathrm{Br}^{-}, \mathrm{HSO}_{4}^{-}\right.$and $\mathrm{CH}_{3} \mathrm{COO}^{-}$as the tetrabutylammonium salts). For each of the compounds, we observed no emission spectral changes for any of these anions, demonstrating the selectivity for $\mathrm{F}^{-}$. Figure 7 displays the ratio of the maximum emission intensities at the new band ( $I_{\text {compound-F- }}$ ) and first peak ( $\left.I_{\text {compound }}\right)$ for the several anions tested. The corresponding intensity ratio for the free compounds (without anion) at the same wavelengths is shown for comparison. The high electronegativity and basicity of $\mathrm{F}^{-}$may justify this selectivity.

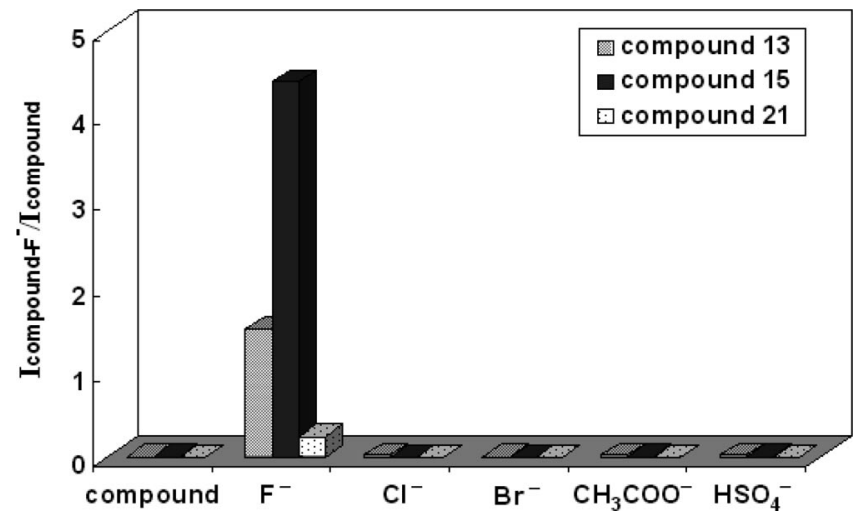

Figure 7. Response of $\mathbf{1 3}, \mathbf{1 5}$ and $\mathbf{2 1}$ to different anions in fluorescence titrations.

\section{Conclusions}

Several new pyrrole-fused compounds were prepared in good yields from brominated dehydroamino acids and arylboronic acids by a Suzuki-Miyaura cross coupling followed by a $\mathrm{Pd} / \mathrm{Cu}$-mediated $\mathrm{C}-\mathrm{N}$ intramolecular cyclisation. As expected, the Suzuki products maintained the stereochemistry of the $\beta$-brominated dehydroamino acid starting material. The cyclisation of $(Z)-\beta$-aryldehydrophenylalanines gave mainly the product that results from isomerisation followed by cyclisation.

The photophysical properties of the new indole derivatives were studied in four solvents of different polarity. All compounds showed reasonably high quantum yields in all solvents $(16-85 \%)$ and different solvent sensitivity of their fluorescence emission, which indicated their potential use as fluorescent probes.

Of all the compounds prepared, three $(13,15$ and 21) showed significant spectral changes in the fluorescence emission upon $\mathrm{F}^{-}$addition with a decrease in intensity and the appearance of a new band at longer wavelengths. Selectivity tests performed with other anions $\left(\mathrm{Cl}^{-}, \mathrm{Br}^{-}, \mathrm{HSO}_{4}^{-}\right.$ and $\mathrm{CH}_{3} \mathrm{COO}^{-}$) revealed no emission spectral changes, indicating a selectivity of these compounds towards $\mathrm{F}^{-}$.

\section{Experimental Section}

Materials and Methods: Melting points [ $\left.{ }^{\circ} \mathrm{C}\right]$ were determined with a Gallenkamp apparatus and are uncorrected. ${ }^{1} \mathrm{H}$ and ${ }^{13} \mathrm{C}$ NMR spectra were recorded with a Bruker Avance $\mathrm{II}^{+}$spectrometer at 400 and $100.6 \mathrm{MHz}$, respectively. Chemical shifts and coupling constants are given in ppm and $\mathrm{Hz}$, respectively. ${ }^{1} \mathrm{H}-{ }^{13} \mathrm{C}$ heteronuclear correlations, HMQC, HMBC and NOE experiments were also performed. HRMS (EI or ESI) data were recorded by the mass spectrometry service of the University of Vigo, Spain. Elemental analysis was performed with a LECO CHNS 932 elemental analyser. The reactions were monitored by thin layer chromatography (TLC). Column chromatography was performed on Macherey-Nagel silica gel (230-400 mesh). Petroleum ether refers to the fraction that boils at $40-60{ }^{\circ} \mathrm{C}$. When a solvent gradient was used, polarity was increased from that of neat petroleum ether with diethyl ether in $10 \%$ steps until the isolation of the product. $\mathrm{PdCl}_{2} \mathrm{dppf} \cdot \mathrm{CH}_{2} \mathrm{Cl}_{2}$ 
(1:1) refers to $\left[1,1^{\prime}\right.$-bis(diphenylphosphanyl)ferrocene]dichloridopalladium(II)-dichloromethane complex adduct.

Synthesis of $(Z)-1,(E)-1,(Z)-2,(E)-2$ and 9: The synthesis of these compounds is described elsewhere. ${ }^{[18-20]}$

General Procedure for the Synthesis of $\beta$-Substituted Dehydroamino Acid Derivatives: To a solution of the $\beta$-bromodehydroamino acid derivative in $\mathrm{THF} / \mathrm{H}_{2} \mathrm{O}(1: 1)(0.05 \mathrm{M})$ boronic acid (1.5 or 5 equiv.), $\mathrm{PdCl}_{2} \mathrm{dppf} \cdot \mathrm{CH}_{2} \mathrm{Cl}_{2}$ (1:1) (10 mol-\%) and $\mathrm{Cs}_{2} \mathrm{CO}_{3}$ (1.4 equiv.) were added. The reaction mixture was heated at $90{ }^{\circ} \mathrm{C}$, and the reaction was monitored by TLC until all of the $\beta$-bromodehydroamino acid was consumed $(1-3 \mathrm{~h})$. The solvent was removed under reduced pressure, and the residue was dissolved in ethyl acetate $(100 \mathrm{~mL})$. The organic layer was washed with water and brine $(2 \times 30 \mathrm{~mL}$ each), dried with $\mathrm{MgSO}_{4}$, and the solvent was removed. The residue was submitted to column chromatography.

Methyl (Z)-2-(tert-Butoxycarbonylamino)-3-(phenanthracen-9-yl)but-2-enoate $[(Z)-3]$ : Compound $(Z)-\mathbf{3}$ was prepared from $(Z)-\mathbf{1}$ $(0.5 \mathrm{mmol}, 147 \mathrm{mg})$ and 9-phenanthracenylboronic acid according to the general procedure described above and with heating for $1 \mathrm{~h}$. Column chromatography with diethyl ether/petroleum ether $(1: 4)$ gave (Z)-3 (120 mg, 61\%) as a white solid. M.p. $159.0-160.0{ }^{\circ} \mathrm{C}$ (from diethyl ether/petroleum ether). ${ }^{1} \mathrm{H}$ NMR (400 $\mathrm{MHz}, \mathrm{CDCl}_{3}$ ): $\delta=1.27\left(\mathrm{~s}, 9 \mathrm{H}, \mathrm{CH}_{3} \mathrm{Boc}\right), 2.38\left(\mathrm{~s}, 3 \mathrm{H}, \mathrm{CH}_{3}\right), 3.95\left(\mathrm{~s}, 3 \mathrm{H}, \mathrm{OCH}_{3}\right)$, 5.61 (br. s, $1 \mathrm{H}, \mathrm{NH}), 7.59-7.73(\mathrm{~m}, 5 \mathrm{H}, \mathrm{ArH}), 7.89$ (d, $J=8.0 \mathrm{~Hz}$, $2 \mathrm{H} \mathrm{ArH}), 8.72(\mathrm{~d}, J=8.4 \mathrm{~Hz}, 1 \mathrm{H}, \mathrm{ArH}), 8.77(\mathrm{~d}, J=8.0 \mathrm{~Hz}, 1$ $\mathrm{H}, \mathrm{ArH}) \mathrm{ppm} .{ }^{13} \mathrm{C} \mathrm{NMR}\left(100.6 \mathrm{MHz}, \mathrm{CDCl}_{3}\right): \delta=21.03\left(\mathrm{CH}_{3}\right)$, $27.98\left[\mathrm{C}\left(\mathrm{CH}_{3}\right)_{3}\right], 52.08\left(\mathrm{OCH}_{3}\right), 80.67\left[\mathrm{OC}\left(\mathrm{CH}_{3}\right)_{3}\right], 122.58(\mathrm{CH})$, $123.22(\mathrm{CH}), 125.28(\mathrm{CH}), 125.53(\mathrm{CH}), 126.06(\mathrm{C}), 126.95(\mathrm{CH})$, $127.05(\mathrm{CH}), 127.06(\mathrm{CH}), 127.30(\mathrm{CH}), 128.48(\mathrm{C}), 128.64(\mathrm{CH})$, 130.10 (C), 130.77 (C), 131.38 (C), 131.93 (C), 136.22 (C), 152.96 $(\mathrm{C}=\mathrm{O}), 165.54(\mathrm{C}=\mathrm{O})$ ppm. HRMS (micrOTOF): calcd. for $\mathrm{C}_{24} \mathrm{H}_{26} \mathrm{NO}_{4}[\mathrm{M}+\mathrm{H}]^{+}$392.18618; found 392.18563 .

Methyl (E)-2-(tert-Butoxycarbonylamino)-3-(phenanthracen-9-yl)but-2-enoate $[(\boldsymbol{E})$-3]: Compound $(E)-\mathbf{3}$ was prepared from $(E)-\mathbf{1}$ $(0.5 \mathrm{mmol}, 147 \mathrm{mg})$ and 9-phenanthracenylboronic acid according to the general procedure described above and with heating for $1 \mathrm{~h}$. Column chromatography with diethyl ether/petroleum ether (1:3) gave $(E)-3(128 \mathrm{mg}, 65 \%)$ as a white solid. M.p. $143.0-144.0^{\circ} \mathrm{C}$ (from diethyl ether/petroleum ether). ${ }^{1} \mathrm{H}$ NMR (400 $\mathrm{MHz}, \mathrm{CDCl}_{3}$ ): $\delta=1.57$ (s, $\left.9 \mathrm{H}, \mathrm{CH}_{3} \mathrm{Boc}\right), 2.27\left(\mathrm{~s}, 3 \mathrm{H}, \mathrm{CH}_{3}\right), 3.24$ (s, $\left.3 \mathrm{H}, \mathrm{OCH}_{3}\right)$, 6.28 (br. s, $1 \mathrm{H}, \mathrm{NH}), 7.46$ (s, $1 \mathrm{H}, \mathrm{ArH}), 7.56-7.69$ (m, $4 \mathrm{H}, \mathrm{ArH})$, $7.83(\mathrm{dd}, J=7.8,1.2 \mathrm{~Hz}, 1 \mathrm{H}, \mathrm{ArH}), 7.94(\mathrm{~d}, J=8.0 \mathrm{~Hz}, 1 \mathrm{H}$, ArH), $8.68(\mathrm{~d}, J=8.4 \mathrm{~Hz}, 1 \mathrm{H}, \mathrm{ArH}), 8.73(\mathrm{~d}, J=8.4 \mathrm{~Hz}, 1 \mathrm{H}$, ArH) ppm. ${ }^{13} \mathrm{C}$ NMR (100.6 MHz, $\left.\mathrm{CDCl}_{3}\right): \delta=22.32\left(\mathrm{CH}_{3}\right), 28.28$ $\left[\mathrm{C}\left(\mathrm{CH}_{3}\right)_{3}\right], 51.63\left(\mathrm{OCH}_{3}\right), 80.75\left[\mathrm{OC}\left(\mathrm{CH}_{3}\right)_{3}\right], 122.51(\mathrm{CH}), 122.86$ $(\mathrm{CH}), 124.18(\mathrm{CH}), 125.33(\mathrm{C}), 126.11(\mathrm{CH}), 126.46(\mathrm{CH}), 126.62$ $(\mathrm{CH}), 126.76(\mathrm{CH}), 128.50(\mathrm{CH}), 129.88(\mathrm{C}), 130.32(\mathrm{C}), 131.43$ (C), 138.20 (C), 140.93 (C), $153.41(\mathrm{C}=\mathrm{O}), 165.11(\mathrm{C}=\mathrm{O}) \mathrm{ppm}$. HRMS (micrOTOF): calcd. for $\mathrm{C}_{24} \mathrm{H}_{26} \mathrm{NO}_{4}[\mathrm{M}+\mathrm{H}]^{+} 392.18618$; found 392.18563 .

Methyl (Z)-2-(tert-Butoxycarbonylamino)-3-(phenanthracen-9-yl)-3phenylacrylate $[(Z)-4]$ : Compound $(Z)-\mathbf{4}$ was prepared from $(Z)-2$ $(0.50 \mathrm{mmol}, 178 \mathrm{mg})$ and 9-phenanthracenylboronic acid according to the general procedure described above and with heating for $1 \mathrm{~h}$. Column chromatography with diethyl ether/petroleum ether $(1: 3)$ gave (Z)-4 (185 mg, 82\%) as a white solid. M.p. $168.0-169.0^{\circ} \mathrm{C}$ (from diethyl ether/petroleum ether). ${ }^{1} \mathrm{H}$ NMR (400 MHz, $\mathrm{CDCl}_{3}$ ): $\delta=1.33$ (s, $\left.9 \mathrm{H}, \mathrm{CH}_{3} \mathrm{Boc}\right), 3.70\left(\mathrm{~s}, 3 \mathrm{H}, \mathrm{OCH}_{3}\right), 5.77$ (br. s, $1 \mathrm{H}$, $\mathrm{NH}), 7.26-7.30(\mathrm{~m}, 5 \mathrm{H}, \mathrm{ArH}), 7.60-7.65$ (m, $3 \mathrm{H}, \mathrm{ArH}), 7.69$ $7.74(\mathrm{~m}, 2 \mathrm{H}, \operatorname{ArH}), 7.85(\mathrm{~d}, J=7.6 \mathrm{~Hz}, 1 \mathrm{H}, \operatorname{ArH}), 8.12(\mathrm{~d}, J=$ $8.4 \mathrm{~Hz}, 1 \mathrm{H}, \mathrm{ArH}), 8.74(\mathrm{~d}, J=8.0 \mathrm{~Hz}, 1 \mathrm{H}, \mathrm{ArH}), 8.78(\mathrm{~d}, J=$ $8.0 \mathrm{~Hz}, 1 \mathrm{H}, \mathrm{ArH}) \mathrm{ppm} .{ }^{13} \mathrm{C}$ NMR $\left(100.6 \mathrm{MHz}, \mathrm{CDCl}_{3}\right): \delta=27.99$
$\left[\mathrm{C}\left(\mathrm{CH}_{3}\right)_{3}\right], 52.22\left(\mathrm{OCH}_{3}\right), 81.27\left[\mathrm{OC}\left(\mathrm{CH}_{3}\right)_{3}\right], 122.58(\mathrm{CH}), 123.11$ $(\mathrm{CH}), 125.85(\mathrm{CH}), 126.95(\mathrm{CH}), 127.06(\mathrm{CH}), 127.36(\mathrm{CH}), 127.44$ $(\mathrm{CH}), 127.84(\mathrm{CH}), 127.90(\mathrm{C}), 128.18(\mathrm{CH}), 128.34(\mathrm{CH}), 128.87$ $(\mathrm{CH}), 129.01(\mathrm{CH}), 129.41(\mathrm{C}), 130.36(\mathrm{C}), 130.80(\mathrm{C}), 131.29(\mathrm{C})$, $134.50(\mathrm{C}), 139.44(\mathrm{C}), 152.50(\mathrm{C}=\mathrm{O}), 166.27(\mathrm{C}=\mathrm{O}) \mathrm{ppm}$. HRMS (micrOTOF): calcd. for $\mathrm{C}_{29} \mathrm{H}_{28} \mathrm{NO}_{4}[\mathrm{M}+\mathrm{H}]^{+} 454.20183$; found 454.20128.

Methyl (E)-2-(tert-Butoxycarbonylamino)-3-(phenanthracen-9-yl)-3phenylacrylate $[(\boldsymbol{E})-\mathbf{4}]$ : Compound $(E)-\mathbf{4}$ was prepared from $(E)-\mathbf{2}$ $(0.50 \mathrm{mmol}, 178 \mathrm{mg})$ and 9-phenanthracenylboronic acid according to the general procedure described above and with heating for $2 \mathrm{~h}$. Column chromatography with diethyl ether/petroleum ether (1:4) gave $(E)-4(132 \mathrm{mg}, 58 \%)$ as a white solid. M.p. $173.0-174.0^{\circ} \mathrm{C}$ (from diethyl ether/petroleum ether). ${ }^{1} \mathrm{H} \mathrm{NMR}\left(400 \mathrm{MHz}, \mathrm{CDCl}_{3}\right.$ ): $\delta=1.52$ (s, $9 \mathrm{H}, \mathrm{CH}_{3}$ Boc), $3.23\left(\mathrm{~s}, 3 \mathrm{H}, \mathrm{OCH}_{3}\right), 6.42$ (br. s, $1 \mathrm{H}$, NH), 7.24-7.28 (m, 1 H, ArH), 7.31-7.35 (m, 2 H, ArH), 7.427.49 (m, $3 \mathrm{H}, \mathrm{ArH}), 7.57-7.69$ (m, $4 \mathrm{H}, \mathrm{ArH}), 7.88-7.94$ (m, $2 \mathrm{H}$, $\mathrm{ArH}), 8.67$ (d, $J=8.4 \mathrm{~Hz}, 2 \mathrm{H}, \mathrm{ArH}) \mathrm{ppm} .{ }^{13} \mathrm{C} \mathrm{NMR}(100.6 \mathrm{MHz}$, $\left.\mathrm{CDCl}_{3}\right): \delta=28.17\left[\mathrm{C}\left(\mathrm{CH}_{3}\right)_{3}\right], 51.82\left(\mathrm{OCH}_{3}\right), 81.36\left[\mathrm{OC}\left(\mathrm{CH}_{3}\right)_{3}\right]$, $122.49(\mathrm{CH}), 122.63(\mathrm{CH}), 126.46(\mathrm{CH}), 126.62(\mathrm{CH}), 126.71(\mathrm{CH})$, $126.91(\mathrm{CH}), 127.16(\mathrm{CH}), 127.75(\mathrm{C}), 128.02(\mathrm{CH}), 128.30(\mathrm{CH})$, $128.70(\mathrm{CH}), 128.83(\mathrm{CH}), 129.03(\mathrm{CH}), 130.37(\mathrm{C}), 130.58(\mathrm{C})$, 130.74 (C), 131.17 (C), 132.32 (C), 135.76 (C), 137.65 (C), 152.86 $(\mathrm{C}=\mathrm{O}), 166.12(\mathrm{C}=\mathrm{O}) \mathrm{ppm}$. HRMS (micrOTOF): calcd. for $\mathrm{C}_{29} \mathrm{H}_{27} \mathrm{NNaO}_{4}[\mathrm{M}]^{+}$476.18378; found 476.18323.

Methyl (Z)-2-(tert-Butoxycarbonylamino)-(1,2-dihydroacenaphthylen-5-yl)but-2-enoate $[(Z)-5]$ : Compound $(Z)-5$ was prepared from (Z)-1 $(0.5 \mathrm{mmol}, 147 \mathrm{mg})$ and (1,2-dihydroacenaphthylen-5-yl)boronic acid according to the general procedure described above and with heating for $1 \mathrm{~h}$. Column chromatography with diethyl ether/ petroleum ether (3:7) gave $(Z)-5(133 \mathrm{mg}, 72 \%)$ as a white solid. M.p. $106-107^{\circ} \mathrm{C}$ (from diethyl ether/petroleum ether). ${ }^{1} \mathrm{H}$ NMR (400 MHz, $\left.\mathrm{CDCl}_{3}\right): \delta=1.32\left(\mathrm{~s}, 9 \mathrm{H}, \mathrm{CH}_{3} \mathrm{Boc}\right), 2.32\left(\mathrm{~s}, 3 \mathrm{H}, \mathrm{CH}_{3}\right)$, 3.43 (s, $4 \mathrm{H}, 2 \mathrm{CH}_{2}$ ), 3.91 (s, $\left.3 \mathrm{H}, \mathrm{OCH}_{3}\right), 5.56$ (br. s, $1 \mathrm{H}, \mathrm{NH}$ ), 7.25-7.33 (m, $3 \mathrm{H}, \mathrm{ArH}), 7.43-7.49$ (m, $2 \mathrm{H}, \mathrm{ArH}) \mathrm{ppm} .{ }^{13} \mathrm{C} \mathrm{NMR}$ $\left(100.6 \mathrm{MHz}, \mathrm{CDCl}_{3}\right): \delta=21.15\left(\mathrm{CH}_{3}\right), 28.04\left[\mathrm{C}\left(\mathrm{CH}_{3}\right)_{3}\right], 30.11$ $\left(\mathrm{CH}_{2}\right), 30.44\left(\mathrm{CH}_{2}\right), 51.96\left(\mathrm{OCH}_{3}\right), 80.50\left[\mathrm{OC}\left(\mathrm{CH}_{3}\right)_{3}\right], 119.15$ $(\mathrm{CH}), 119.74(\mathrm{CH}), 119.94(\mathrm{CH}), 125.36(\mathrm{C}), 126.91(\mathrm{CH}), 128.00$ (C), $128.61(\mathrm{CH}), 131.53(\mathrm{C}), 132.74(\mathrm{C}), 139.50(\mathrm{C}), 146.44(\mathrm{C})$, $146.53(\mathrm{C}), 153.10 \quad(\mathrm{C}=\mathrm{O}), 165.76(\mathrm{C}=\mathrm{O})$ ppm. $\mathrm{C}_{22} \mathrm{H}_{25} \mathrm{NO}_{4}$ (367.44): calcd. C 71.91, H 6.86, N 3.81; found C 71.46, H 6.34, N 3.75 .

Methyl (E)-2-(tert-Butoxycarbonylamino)-(1,2-dihydroacenaphthylen-5-yl)but-2-enoate $[(\boldsymbol{E})-5]$ : Compound $(E)-5$ was prepared from (E)-1 (0.5 mmol, $147 \mathrm{mg})$ and (1,2-dihydroacenaphthylen-5-yl)boronic acid according to the general procedure described above and with heating for $1 \mathrm{~h}$. Column chromatography with diethyl ether/ petroleum ether (3:7) gave $(E)-5(149 \mathrm{mg}, 81 \%)$ as a white solid. M.p. $131.0-132.0^{\circ} \mathrm{C}$ (from diethyl ether/petroleum ether). ${ }^{1} \mathrm{H}$ NMR (400 MHz, $\left.\mathrm{CDCl}_{3}\right): \delta=1.53\left(\mathrm{~s}, 9 \mathrm{H}, \mathrm{CH}_{3} \mathrm{Boc}\right), 2.23$ (s, 3 $\left.\mathrm{H}, \mathrm{CH}_{3}\right), 3.03$ (s, $3 \mathrm{H}, \mathrm{OCH}_{3}$ ), 3.40 (s, $4 \mathrm{H}, 2 \mathrm{CH}_{2}$ ), 6.16 (br. s, 1 $\mathrm{H}, \mathrm{NH}), 7.17$ (d, J = 7.2 Hz, 1 H, ArH), 7.22-7.28 (m, $2 \mathrm{H}, \mathrm{ArH})$, 7.40-7.45 (m, $1 \mathrm{H}, \mathrm{ArH}), 7.54$ (d, $J=8.1 \mathrm{~Hz}, 1 \mathrm{H}, \mathrm{ArH}) \mathrm{ppm} .{ }^{13} \mathrm{C}$

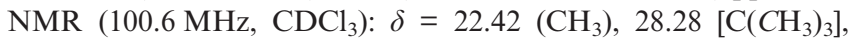
$30.07\left(\mathrm{CH}_{2}\right), 30.48\left(\mathrm{CH}_{2}\right), 51.63\left(\mathrm{OCH}_{3}\right), 80.62\left[\mathrm{OC}\left(\mathrm{CH}_{3}\right)_{3}\right], 118.70$ $(\mathrm{CH}), 119.28(\mathrm{CH}), 120.29(\mathrm{CH}), 124.86(\mathrm{C}), 125.83(\mathrm{CH}), 127.96$ (CH), 129.02 (C), $134.68(\mathrm{C}), 139.19$ (C), $140.46(\mathrm{C}), 145.44(\mathrm{C})$, $146.12(\mathrm{C}), 153.41(\mathrm{C}=\mathrm{O}), 165.21 \quad(\mathrm{C}=\mathrm{O})$ ppm. $\mathrm{C}_{22} \mathrm{H}_{25} \mathrm{NO}_{4}$ (367.44): calcd. C 71.91, H 6.86, N 3.81; found C 71.97, H 6.48, N 3.74 .

Methyl (Z)-2-(tert-Butoxycarbonylamino)-3-phenyl-3-(1,2-dihydroacenaphthylen-5-yl)acrylate $[(Z)-6]$ : Compound $(Z)-6$ was prepared 
from (Z)-2 (0.5 mmol, $178 \mathrm{mg})$ and (1,2-dihydroacenaphthylen-5yl)boronic acid according to the general procedure described above and with heating for $1.5 \mathrm{~h}$. Column chromatography with diethyl ether/petroleum ether (1:3) gave (Z)-6 (170 mg, 79\%) as a white solid. M.p. $160.0-161.0^{\circ} \mathrm{C}$ (from diethyl ether/petroleum ether). ${ }^{1} \mathrm{H}$ NMR (400 MHz, $\left.\mathrm{CDCl}_{3}\right): \delta=1.37\left(\mathrm{~s}, 9 \mathrm{H}, \mathrm{CH}_{3} \mathrm{Boc}\right.$ ), 3.41-3.46 (m, $4 \mathrm{H}, 2 \mathrm{CH}_{2}$ ), 3.64 (s, $3 \mathrm{H}, \mathrm{OCH}_{3}$ ), 5.76 (br. s, $1 \mathrm{H}, \mathrm{NH}$ ), 7.17$7.21(\mathrm{~m}, 3 \mathrm{H}, \mathrm{ArH}), 7.24-7.28(\mathrm{~m}, 4 \mathrm{H}, \mathrm{ArH}), 7.32(\mathrm{~d}, J=6.8 \mathrm{~Hz}$, $1 \mathrm{H}, \mathrm{ArH}), 7.44(\mathrm{t}, J=7.6 \mathrm{~Hz}, 1 \mathrm{H}, \operatorname{ArH}), 7.60(\mathrm{~d}, J=8.4 \mathrm{~Hz}, 1$ $\mathrm{H}$, ArH) ppm. ${ }^{13} \mathrm{C}$ NMR $\left(100.6 \mathrm{MHz}, \mathrm{CDCl}_{3}\right): \delta=28.03[\mathrm{C}-$ $\left.\left(\mathrm{CH}_{3}\right)_{3}\right], 30.17\left(\mathrm{CH}_{2}\right), 30.42\left(\mathrm{CH}_{2}\right), 52.06\left(\mathrm{OCH}_{3}\right), 80.98[\mathrm{OC}-$ $\left.\left(\mathrm{CH}_{3}\right)_{3}\right], 119.22(\mathrm{CH}), 119.73(\mathrm{CH}), 120.45(\mathrm{CH}), 126.92(\mathrm{C})$, $127.64(\mathrm{C}), 128.03(\mathrm{CH}), 128.61(\mathrm{CH}), 128.81(\mathrm{CH}), 129.05(\mathrm{C})$, $130.40(\mathrm{CH}), 131.15(\mathrm{C}), 139.54(\mathrm{C}), 140.32$ (C), 146.42 (C), 147.24 (C), $152.76(\mathrm{C}=\mathrm{O}), 166.51(\mathrm{C}=\mathrm{O}) \mathrm{ppm}$. HRMS (micrOTOF): calcd. for $\mathrm{C}_{27} \mathrm{H}_{28} \mathrm{NO}_{4}[\mathrm{M}+\mathrm{H}]^{+}$430.20183; found 430.20128.

Methyl (E)-2-(tert-Butoxycarbonylamino)-3-(1,2-dihydroacenaphthylen-5-yl)-3-phenylacrylate $[(\boldsymbol{E})-6]$ : Compound $(E)-6$ was prepared from $(E)-2(0.5 \mathrm{mmol}, 178 \mathrm{mg})$ and (1,2-dihydroacenaphthylen-5yl)boronic acid according to the general procedure described above and with heating for $2 \mathrm{~h}$. Column chromatography with diethyl ether/petroleum ether (1:4) gave $(E)-6(154 \mathrm{mg}, 72 \%)$ as a white solid. M.p. $157.0-158.0{ }^{\circ} \mathrm{C}$ (from diethyl ether/petroleum ether). ${ }^{1} \mathrm{H}$ NMR (400 MHz, $\left.\mathrm{CDCl}_{3}\right): \delta=1.48\left(\mathrm{~s}, 9 \mathrm{H}, \mathrm{CH}_{3} \mathrm{Boc}\right.$ ), 3.33 (s, 3 $\left.\mathrm{H}, \mathrm{OCH}_{3}\right), 3.39$ (s, $\left.4 \mathrm{H}, 2 \mathrm{CH}_{2}\right), 6.31$ (br. s, $1 \mathrm{H}, \mathrm{NH}$ ), 7.23-7.38 $(\mathrm{m}, 10 \mathrm{H}, \mathrm{ArH}) \mathrm{ppm} .{ }^{13} \mathrm{C} \mathrm{NMR}\left(100.6 \mathrm{MHz}, \mathrm{CDCl}_{3}\right): \delta=28.17$ $\left[\mathrm{C}\left(\mathrm{CH}_{3}\right)_{3}\right], \quad 30.06\left(\mathrm{CH}_{2}\right), 30.44\left(\mathrm{CH}_{2}\right), 51.82\left(\mathrm{OCH}_{3}\right), 81.13$ $\left[\mathrm{OC}\left(\mathrm{CH}_{3}\right)_{3}\right], 118.61(\mathrm{CH}), 119.29(\mathrm{CH}), 120.98(\mathrm{CH}), 126.95(\mathrm{C})$, $127.92(\mathrm{CH}), 128.05(\mathrm{C}), 128.12(\mathrm{CH}), 128.74(\mathrm{CH}), 129.21(\mathrm{CH})$, 129.25 (CH), $130.24(\mathrm{C}), 132.54(\mathrm{C}), 138.68(\mathrm{C}), 139.48(\mathrm{C}), 145.94$ (C), $146.54(\mathrm{C}), 152.94(\mathrm{C}=\mathrm{O}), 166.31(\mathrm{C}=\mathrm{O})$ ppm. HRMS (EI): calcd. for $\mathrm{C}_{27} \mathrm{H}_{27} \mathrm{NNaO}_{4}[\mathrm{M}]^{+}$452.18323; found 452.18279 .

Methyl (Z)-2-(tert-Butoxycarbonylamino)-3-(naphthalen-1-yl)but-2enoate $[(Z)-7]$ : Compound $(Z)-7$ was prepared from $(Z)-\mathbf{1}$ $(0.5 \mathrm{mmol}, 147 \mathrm{mg})$ and (naphthalen-1-yl)boronic acid according to the general procedure described above and with heating for $1 \mathrm{~h}$. Column chromatography with diethyl ether/petroleum ether (3:7) gave $(Z)-7(125 \mathrm{mg}, 73 \%)$ as a white solid. M.p. $88.0-89.0^{\circ} \mathrm{C}$ (from diethyl ether/petroleum ether). ${ }^{1} \mathrm{H}$ NMR (400 $\left.\mathrm{MHz}, \mathrm{CDCl}_{3}\right): \delta=$ 1.30 (s, $\left.9 \mathrm{H}, \mathrm{CH}_{3} \mathrm{Boc}\right), 2.32\left(\mathrm{~s}, 3 \mathrm{H}, \mathrm{CH}_{3}\right), 3.92\left(\mathrm{~s}, 3 \mathrm{H}, \mathrm{OCH}_{3}\right)$, 5.48 (br. s, $1 \mathrm{H}, \mathrm{NH}), 7.30$ (s, $1 \mathrm{H}, \mathrm{ArH}), 7.49-7.52$ (m, $3 \mathrm{H}, \mathrm{ArH})$, 7.78-7.85 (m, $2 \mathrm{H}, \mathrm{ArH}), 7.88-7.90$ (m, $1 \mathrm{H}, \mathrm{ArH}) \mathrm{ppm} .{ }^{13} \mathrm{C} \mathrm{NMR}$ $\left(100.6 \mathrm{MHz}, \mathrm{CDCl}_{3}\right): \delta=21.19\left(\mathrm{CH}_{3}\right), 27.99\left[\mathrm{C}\left(\mathrm{CH}_{3}\right)_{3}\right], 52.03$ $\left(\mathrm{OCH}_{3}\right), 82.57\left[\mathrm{OC}\left(\mathrm{CH}_{3}\right)_{3}\right], 124.55(\mathrm{CH}), 124.83(\mathrm{CH}), 125.66$ $(\mathrm{CH}), 125.72(\mathrm{C}), 126.26(\mathrm{CH}), 126.82(\mathrm{CH}), 128.24(\mathrm{CH}), 128.61$ $(\mathrm{CH}), 129.48(\mathrm{C}), 132.16(\mathrm{C}), 133.83(\mathrm{C}), 137.51(\mathrm{C}), 152.95(\mathrm{C}=\mathrm{O})$, $165.58(\mathrm{C}=\mathrm{O})$ ppm. $\mathrm{C}_{20} \mathrm{H}_{23} \mathrm{NO}_{4}$ (341.40): calcd. C 70.36, H 6.79, N 4.10; found C 70.32, H 6.80, N 4.07.

Methyl (E)-2-(tert-Butoxycarbonylamino)-3-(naphthalen-1-yl)but-2enoate $[(\boldsymbol{E})-7]$ : Compound $(E)-\mathbf{8}$ was prepared from $(E)-\mathbf{1}$ $(1.0 \mathrm{mmol}, 294 \mathrm{mg})$ and (naphthalen-1-yl)boronic acid according to the general procedure described above and with heating for $1 \mathrm{~h}$. Column chromatography with diethyl ether/petroleum ether $(3: 7)$ gave $(E)-7$ (250 mg, 73\%) as a white solid. M.p. $79.0-80.0^{\circ} \mathrm{C}$ (from diethyl ether/petroleum ether). ${ }^{1} \mathrm{H}$ NMR $\left(400 \mathrm{MHz} \mathrm{CDCl}_{3}\right): \delta=$ 1.55 (s, $\left.9 \mathrm{H}, \mathrm{CH}_{3} \mathrm{Boc}\right), 2.24\left(\mathrm{~s}, 3 \mathrm{H}, \mathrm{CH}_{3}\right), 3.25\left(\mathrm{~s}, 3 \mathrm{H}, \mathrm{OCH}_{3}\right)$, 6.22 (br. s, $1 \mathrm{H}, \mathrm{NH}), 7.20$ (d, $J=6.8 \mathrm{~Hz}, 1 \mathrm{H}, \mathrm{ArH}), 7.40-7.49$ (m, $3 \mathrm{H}, \mathrm{ArH}), 7.77$ (d, $J=8.4 \mathrm{~Hz}, 1 \mathrm{H}, \mathrm{ArH}), 7.84-7.88(\mathrm{~m}, 2 \mathrm{H}$, ArH) ppm. ${ }^{13} \mathrm{C}$ NMR (100.6 MHz, $\left.\mathrm{CDCl}_{3}\right): \delta=22.59\left(\mathrm{CH}_{3}\right), 28.27$ $\left[\mathrm{C}\left(\mathrm{CH}_{3}\right)_{3}\right], 51.56\left(\mathrm{OCH}_{3}\right), 80.70\left[\mathrm{OC}\left(\mathrm{CH}_{3}\right)_{3}\right], 123.80(\mathrm{CH}), 125.15$ $(\mathrm{CH}), 125.27(\mathrm{CH}), 125.74(\mathrm{CH}), 126.13(\mathrm{CH}), 127.42(\mathrm{CH}), 128.22$ (CH), 130.58 (C), 133.41 (C), 139.49 (C), 141.11 (C), 150.47 (C),
$153.36(\mathrm{C}=\mathrm{O}), 165.04(\mathrm{C}=\mathrm{O})$ ppm. HRMS (EI): calcd. for $\mathrm{C}_{20} \mathrm{H}_{23} \mathrm{NNaO}_{4}[\mathrm{M}]^{+}$364.15193; found 364.15159.

Methyl (Z)-2-(tert-Butoxycarbonylamino)-3-(naphthalen-1-yl)-3phenylacrylate $[(Z)-8]$ : Compound $(Z)-8$ was prepared from $(Z)-2$ $(0.5 \mathrm{mmol}, 178 \mathrm{mg})$ and (naphthalen-1-yl)boronic acid according to the general procedure described above and with heating for $1 \mathrm{~h}$. Column chromatography with diethyl ether/petroleum ether $(1: 2)$ gave $(Z)-8$ (149 mg, 74\%) as a white solid. M.p. $165.0-166.0^{\circ} \mathrm{C}$ (from diethyl ether/petroleum ether). ${ }^{1} \mathrm{H}$ NMR (400 $\mathrm{MHz}, \mathrm{CDCl}_{3}$ ): $\delta=1.35$ (s, $9 \mathrm{H}, \mathrm{CH}_{3}$ Boc), 3.66 (s, $\left.3 \mathrm{H}, \mathrm{OCH}_{3}\right), 5.67$ (br. s, $1 \mathrm{H}$, $\mathrm{NH}), 7.18-7.30(\mathrm{~m}, 6 \mathrm{H}, \mathrm{ArH}), 7.47-7.54(\mathrm{~m}, 3 \mathrm{H}, \mathrm{ArH}), 7.86-$ $7.92(\mathrm{~m}, 2 \mathrm{H}, \mathrm{ArH}), 8.02(\mathrm{~d}, J=8.0 \mathrm{~Hz}, 1 \mathrm{H}, \mathrm{ArH}) \mathrm{ppm} .{ }^{13} \mathrm{C}$ NMR $\left(100.6 \mathrm{MHz}, \mathrm{CDCl}_{3}\right): \delta=28.00\left[\mathrm{C}\left(\mathrm{CH}_{3}\right)_{3}\right], 52.14\left(\mathrm{OCH}_{3}\right), 81.17$ $\left[\mathrm{OC}\left(\mathrm{CH}_{3}\right)_{3}\right], 125.07(\mathrm{CH}), 125.62(\mathrm{CH}), 126.27(\mathrm{CH}), 127.06(\mathrm{CH})$, $127.57(\mathrm{C}), 127.75(\mathrm{CH}), 128.12(\mathrm{CH}), 128.36(\mathrm{CH}), 128.56(\mathrm{CH})$, $128.89(\mathrm{CH}), 130.57(\mathrm{C}), 133.90(\mathrm{C}), 135.66(\mathrm{C}), 139.74(\mathrm{C}), 152.53$ $(\mathrm{C}=\mathrm{O}), 166.30 \quad(\mathrm{C}=\mathrm{O})$ ppm. HRMS (micrOTOF): calcd. for $\mathrm{C}_{25} \mathrm{H}_{26} \mathrm{NO}_{4}[\mathrm{M}+\mathrm{H}]^{+}$404.18618; found 404.18563.

Methyl (E)-2-(tert-Butoxycarbonylamino)-3-(naphthalen-1-yl)-3phenylacrylate $[(\boldsymbol{E})-\mathbf{8}]$ : Compound $(E)-\mathbf{8}$ was prepared from $(E)-\mathbf{2}$ $(0.5 \mathrm{mmol}, 178 \mathrm{mg})$ and (naphthalen-1-yl)boronic acid according to the general procedure described above and with heating for $1 \mathrm{~h}$. Column chromatography with diethyl ether/petroleum ether (1:2) gave $(E)-8(157 \mathrm{mg}, 78 \%)$ as a white solid. M.p. $155.0-156.0^{\circ} \mathrm{C}$ (from diethyl ether/petroleum ether). ${ }^{1} \mathrm{H}$ NMR (400 $\mathrm{MHz}, \mathrm{CDCl}_{3}$ ): $\delta=1.48$ (s, $9 \mathrm{H}, \mathrm{CH}_{3}$ Boc), 3.23 (s, $\left.3 \mathrm{H}, \mathrm{OCH}_{3}\right), 6.35$ (br. s, $1 \mathrm{H}$, $\mathrm{NH}), 7.24-7.46(\mathrm{~m}, 9 \mathrm{H}, \mathrm{ArH}), 7.80-7.85(\mathrm{~m}, 3 \mathrm{H}, \mathrm{ArH}) \mathrm{ppm} .{ }^{13} \mathrm{C}$ NMR (100.6 MHz, $\left.\mathrm{CDCl}_{3}\right): \delta=28.20\left[\mathrm{C}\left(\mathrm{CH}_{3}\right)_{3}\right], 51.74\left(\mathrm{OCH}_{3}\right)$, $81.17\left[\mathrm{OC}\left(\mathrm{CH}_{3}\right)_{3}\right], 124.99(\mathrm{CH}), 125.76(\mathrm{CH}), 126.06(\mathrm{CH}), 126.15$ $(\mathrm{CH}), 127.33(\mathrm{CH}), 127.54(\mathrm{C}), 128.12(\mathrm{CH}), 128.22(\mathrm{CH}), 128.44$ $(\mathrm{CH}), 128.81(\mathrm{CH}), 129.04(\mathrm{CH}), 131.85(\mathrm{C}), 132.48(\mathrm{C}), 133.71$ (C), 137.10 (C), $138.24(\mathrm{C}), 152.89(\mathrm{C}=\mathrm{O}), 166.06(\mathrm{C}=\mathrm{O}) \mathrm{ppm}$. $\mathrm{C}_{25} \mathrm{H}_{25} \mathrm{NO}_{4}$ (403.47): calcd. C 74.42, $\mathrm{H} \mathrm{6.25,} \mathrm{N} \mathrm{3.47;} \mathrm{found} \mathrm{C}$ 74.52, H 6.07, N 3.43.

Methyl 2-(tert-Butoxycarbonylamino)-3,3-bis(phenanthracen-9-yl)acrylate (10): Compound $\mathbf{1 0}$ was prepared from $9(0.5 \mathrm{mmol}$, $178.4 \mathrm{mg}$ ) and 9-phenanthracenylboronic acid (5 equiv., $2.5 \mathrm{mmol}$ ) according to the general procedure described above and with heating for $2 \mathrm{~h}$. Column chromatography with diethyl ether/petroleum ether (1:3) gave $10(175 \mathrm{mg}, 63 \%)$ as a white solid. M.p. 212.0$213.0{ }^{\circ} \mathrm{C}$ (from ethyl acetate/petroleum ether). ${ }^{1} \mathrm{H}$ NMR $(400 \mathrm{MHz}$, $\mathrm{CDCl}_{3}$ ): $\delta=1.37$ (s, $9 \mathrm{H}, \mathrm{CH}_{3} \mathrm{Boc}$ ), 3.36 (s, $3 \mathrm{H}, \mathrm{OMe}$ ), 5.84 (br. s, $1 \mathrm{H}, \mathrm{NH}), 7.17-7.21$ (m, $1 \mathrm{H}, \mathrm{ArH}), 7.45-7.54$ (m, $3 \mathrm{H}, \mathrm{ArH})$, 7.59-7.80 (m, 8 H, ArH), 7.89-7.91 (m, 2 H, ArH), 8.00-8.02 (m, $1 \mathrm{H}, \mathrm{ArH}), 8.64-8.70(\mathrm{~m}, 2 \mathrm{H}, \mathrm{ArH}), 8.81-8.83$ (m, $1 \mathrm{H}, \mathrm{ArH})$ ppm. ${ }^{13} \mathrm{C}$ NMR $\left(100.6 \mathrm{MHz}, \mathrm{CDCl}_{3}\right): \delta=28.06\left[\left(\mathrm{CH}_{3}\right)_{3} \mathrm{C}\right], 52.13$ $\left(\mathrm{OCH}_{3}\right), 81.21\left[\left(\mathrm{CH}_{3}\right)_{3} \mathrm{C}\right], 122.40(\mathrm{CH}), 122.57(\mathrm{CH}), 122.70(\mathrm{CH})$, 123.57 (CH), $126.27(\mathrm{CH}), 126.56(\mathrm{CH}), 126.75(\mathrm{CH}), 126.83(\mathrm{CH})$, $126.89(\mathrm{CH}), 126.93(\mathrm{CH}), 127.01(\mathrm{CH}), 127.11(\mathrm{CH}), 127.52(\mathrm{CH})$, $128.05(\mathrm{CH}), 128.82(\mathrm{CH}), 128.97(\mathrm{CH}), 128.70(\mathrm{CH}), 129.70(\mathrm{CH})$, 129.80 (C), 130.13 (C), 130.19 (C), 130.45 (C), 130.54 (C), 130.60 (C), 130.69 (C), 130.94 (C), 131.29 (C), 132.95 (C), 135.71 (C), $136.82(\mathrm{C}), 152.74(\mathrm{C}=\mathrm{O}), 166.22(\mathrm{C}=\mathrm{O}) \mathrm{ppm}$. HRMS (micrOTOF): calcd. for $\mathrm{C}_{37} \mathrm{H}_{32} \mathrm{NO}_{4}[\mathrm{M}+\mathrm{H}]^{+}$554.23313; found 554.23258

Methyl 2-(tert-Butoxycarbonylamino)-3,3-bis(1,2-dihydroacenaphthen-5-yl)acrylate (11): Compound 11 was prepared from 9 $(0.25 \mathrm{mmol}, 89.2 \mathrm{mg})$ and 1,2-dihydroacenaphthylen-5-ylboronic acid (5 equiv., $1.25 \mathrm{mmol}$ ) according to the general procedure described above and with heating for $2 \mathrm{~h}$. Column chromatography with diethyl ether/petroleum ether (1:3) gave $\mathbf{1 1}(85 \mathrm{mg}, 67 \%)$ as a white solid. M.p. $121.0-122.0{ }^{\circ} \mathrm{C}$ (from ethyl acetate $/ n$-hexane). ${ }^{1} \mathrm{H}$ 
NMR (400 MHz, [D $\mathrm{D}_{6} \mathrm{DMSO}$ ): $\delta=1.34$ (s, $9 \mathrm{H}, \mathrm{CH}_{3} \mathrm{Boc}$ ), 3.25 (s, $\left.3 \mathrm{H}, \mathrm{OCH}_{3}\right), 3.29-3.39\left(\mathrm{~m}, 4 \mathrm{H}, 2 \mathrm{CH}_{2}\right), 7.00(\mathrm{~d}, J=7.2 \mathrm{~Hz}, 1 \mathrm{H}$, ArH), 7.13-7.25 (m, $6 \mathrm{H}, \mathrm{ArH}), 7.34$ (d, $J=6.8 \mathrm{~Hz}, 1 \mathrm{H}, \mathrm{ArH})$, $7.47(\mathrm{t}, J=8.4 \mathrm{~Hz}, 1 \mathrm{H}, \operatorname{ArH}), 7.74(\mathrm{~d}, J=8.0 \mathrm{~Hz}, 1 \mathrm{H}, \operatorname{ArH})$, 8.10 (br. s, $1 \mathrm{H}, \mathrm{NH}$ ) ppm. ${ }^{13} \mathrm{C}$ NMR (100.6 MHz, [D 6 ]DMSO): $\delta$ $=27.59\left[\mathrm{C}\left(\mathrm{CH}_{3}\right)_{3}\right], 29.22\left(\mathrm{CH}_{2}\right), 29.61\left(\mathrm{CH}_{2}\right), 50.66\left(\mathrm{OCH}_{3}\right), 78.88$ $\left[\mathrm{OC}\left(\mathrm{CH}_{3}\right)_{3}\right], 118.31(\mathrm{CH}), 118.63(\mathrm{CH}), 118.77(\mathrm{CH}), 118.81(\mathrm{CH})$, $119.87(\mathrm{CH}), 120.31(\mathrm{CH}), 127.37(\mathrm{CH}), 127.77(\mathrm{CH}), 127.92(\mathrm{C})$, $128.18(\mathrm{CH}), 128.23(\mathrm{C}), 129.67(\mathrm{C}), 129.74(\mathrm{CH}), 132.08(\mathrm{C})$, 132.98 (C), 134.13 (C), 138.59 (C), 145.33 (C), 145.43 (C), 145.79 (C), $153.00(\mathrm{C}=\mathrm{O}), 165.57(\mathrm{C}=\mathrm{O}) \mathrm{ppm}$. HRMS (micrOTOF): calcd. for $\mathrm{C}_{33} \mathrm{H}_{32} \mathrm{NO}_{4}[\mathrm{M}+\mathrm{H}]^{+}$506.23313; found 506.23258.

Methyl 2-(tert-Butoxycarbonylamino)-3,3-bis(naphthalen-1-yl)acrylate (12): Compound 12 was prepared from $9(0.5 \mathrm{mmol}, 178 \mathrm{mg})$ and (naphthalen-1-yl)boronic acid (5 equiv.) according to the general procedure described above and with heating for $2 \mathrm{~h}$. Column chromatography with diethyl ether/petroleum ether (1:2) gave 12 (160 mg, $71 \%$ ) as a white solid. M.p. $194.0-195.0^{\circ} \mathrm{C}$ (from ethyl acetate/petroleum ether). ${ }^{1} \mathrm{H}$ NMR $\left(400 \mathrm{MHz}, \mathrm{CDCl}_{3}\right): \delta=1.38(\mathrm{~s}$, $9 \mathrm{H}, \mathrm{CH}_{3} \mathrm{Boc}$ ), 3.36 (s, $3 \mathrm{H}, \mathrm{OCH}_{3}$ ), 5.78 (br. s, $1 \mathrm{H}, \mathrm{NH}$ ), 7.12 7.18 (m, $1 \mathrm{H}, \mathrm{ArH}), 7.28-7.36(\mathrm{~m}, 3 \mathrm{H}, \mathrm{ArH}), 7.46-7.50(\mathrm{~m}, 2 \mathrm{H}$, ArH), 7.53-7.69 (m, 2 H, ArH), 7.72-7.88 (m, 4 H, ArH), 7.93 (d, $J=7.6 \mathrm{~Hz}, 1 \mathrm{H}, \mathrm{ArH}), 8.41(\mathrm{~d}, J=7.2 \mathrm{~Hz}, 1 \mathrm{H}, \mathrm{ArH}) \mathrm{ppm} .{ }^{13} \mathrm{C}$ NMR $\left(100.6 \mathrm{MHz}, \mathrm{CDCl}_{3}\right): \delta=28.03\left[\mathrm{C}\left(\mathrm{CH}_{3}\right)_{3}\right], 51.90\left(\mathrm{OCH}_{3}\right)$,

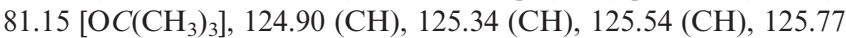
$(\mathrm{CH}), 126.06(\mathrm{CH}), 126.20(\mathrm{CH}), 126.51(\mathrm{CH}), 127.29(\mathrm{CH}), 127.34$ $(\mathrm{CH}), 127.60(\mathrm{CH}), 128.15(\mathrm{CH}), 128.78(\mathrm{CH}), 129.12(\mathrm{CH}), 129.23$ (CH), 129.27 (C), 129.51 (C), 132.00 (C), 133.78 (C), 133.90 (C), 134.72 (C), 136.61 (C), 138.05 (C), $152.82(\mathrm{C}=\mathrm{O}), 166.16(\mathrm{C}=\mathrm{O})$ ppm. HRMS (micrOTOF): calcd. for $\mathrm{C}_{29} \mathrm{H}_{28} \mathrm{NO}_{4}[\mathrm{M}+\mathrm{H}]^{+}$ 454.20183; found 454.20128.

General Procedure for the Intramolecular Cyclisation: To a solution of the $\beta$-substituted or $\beta, \beta$-disubstituted dehydroamino acid derivatives in $\mathrm{DMF}, \mathrm{Pd}(\mathrm{OAc})_{2}(50 \mathrm{~mol}-\%)$ and $\mathrm{Cu}(\mathrm{OAc})_{2} \cdot \mathrm{H}_{2} \mathrm{O}$ (3 equiv.) were added, and the mixture was heated at $160^{\circ} \mathrm{C}$ (the reaction was moniored by TLC). Ethyl acetate $(50 \mathrm{~mL})$ was then added, and the organic layer was washed with water and brine $(2 \times 30 \mathrm{~mL}$, each), dried with $\mathrm{MgSO}_{4}$, and the solvent was removed.

Methyl 3-Methyl-1H-dibenzo[e,g]indole-2-carboxylate (13): Compound $\mathbf{1 3}$ was prepared from $(Z)-\mathbf{3}(0.29 \mathrm{mmol}, 112 \mathrm{mg})$ according to the general procedure described above and with heating for $6 \mathrm{~h}$. Column chromatography with diethyl ether/petroleum ether (1:4) afforded $13(33.4 \mathrm{mg}, 40 \%)$ as a white solid. M.p. $212.0-213.0^{\circ} \mathrm{C}$ (from ethyl acetate/petroleum ether). ${ }^{1} \mathrm{H}$ NMR (400 MHz, $\mathrm{CDCl}_{3}$ ): $\delta=3.05\left(\mathrm{~s}, 3 \mathrm{H}, \mathrm{CH}_{3}\right), 4.01\left(\mathrm{~s}, 3 \mathrm{H}, \mathrm{OCH}_{3}\right), 7.55-7.59(\mathrm{~m}, 1 \mathrm{H}$, ArH), 7.62-7.68 (m, 3 H, ArH), 8.06-8.08 (m, $1 \mathrm{H}, \mathrm{ArH}), 8.53$ (d, $J=8.4 \mathrm{~Hz}, 1 \mathrm{H}, \mathrm{ArH}), 8.67-8.70$ (m, $2 \mathrm{H}, \mathrm{ArH}), 9.56$ (br. s, $1 \mathrm{H}$, $\mathrm{NH})$ ppm. ${ }^{13} \mathrm{C} \mathrm{NMR}\left(100.6 \mathrm{MHz}, \mathrm{CDCl}_{3}\right): \delta=51.60\left(\mathrm{OCH}_{3}\right)$, $119.50(\mathrm{C}), 120.59(\mathrm{CH}), 121.29(\mathrm{C}), 122.37(\mathrm{C}), 123.66(\mathrm{CH})$, $123.78(\mathrm{CH}), 123.90(\mathrm{CH}$ and $\mathrm{C}), 124.33(\mathrm{CH}), 126.46(\mathrm{CH}), 126.91$ $(\mathrm{CH}), 127.13(\mathrm{CH}), 127.77(\mathrm{C}), 129.96(\mathrm{C}), 130.01(\mathrm{C}), 130.67(\mathrm{C})$, $162.71(\mathrm{C}=\mathrm{O})$ ppm. $\mathrm{C}_{19} \mathrm{H}_{15} \mathrm{NO}_{2}$ (289.33): calcd. C 78.87, H 5.23, $\mathrm{N}$ 4.84; found $\mathrm{C} 78.75, \mathrm{H} 5.32, \mathrm{~N} 4.32$.

Methyl 3-(Phenanthren-9-yl)-1H-indole-2-carboxylate (14): Compound $\mathbf{1 4}$ was prepared from $(Z)-\mathbf{4}(0.5 \mathrm{mmol}, 227 \mathrm{mg})$ according to the general procedure described above and with heating for $4 \mathrm{~h}$. Crystallization (diethyl ether/petroleum ether) gave 14 (137 mg, $78 \%$ ) as a white solid. M.p. $102.0-103.0{ }^{\circ} \mathrm{C}$ (from diethyl ether/ petroleum ether). ${ }^{1} \mathrm{H}$ NMR $\left(400 \mathrm{MHz}, \mathrm{CDCl}_{3}\right): \delta=3.59(\mathrm{~s}, 3 \mathrm{H}$, $\left.\mathrm{OCH}_{3}\right), 7.11(\mathrm{t}, J=7.6 \mathrm{~Hz}, 1 \mathrm{H}, \mathrm{ArH}), 7.36-7.49(\mathrm{~m}, 3 \mathrm{H}, \mathrm{ArH})$, 7.54 (d, $J=8.4 \mathrm{~Hz}, 1 \mathrm{H}, \mathrm{ArH}), 7.63-7.74(\mathrm{~m}, 4 \mathrm{H}, \mathrm{ArH}), 7.84(\mathrm{~s}$, $1 \mathrm{H}, \mathrm{ArH}), 7.92(\mathrm{~d}, J=7.2 \mathrm{~Hz}, 1 \mathrm{H}, \mathrm{ArH}), 8.81(\mathrm{t}, J=7.6 \mathrm{~Hz}, 2 \mathrm{H}$,
ArH), 9.46 (br. s, $1 \mathrm{H}, \mathrm{NH}) \mathrm{ppm} .{ }^{13} \mathrm{C} \mathrm{NMR}\left(100.6 \mathrm{MHz}, \mathrm{CDCl}_{3}\right): \delta$ $=51.74\left(\mathrm{OCH}_{3}\right), 111.81(\mathrm{CH}), 120.84(\mathrm{CH}), 121.89(\mathrm{C}), 121.98$ $(\mathrm{CH}), 122.54(\mathrm{CH}), 122.67(\mathrm{CH}), 124.43(\mathrm{C}), 125.86(\mathrm{CH}), 126.24$ $(\mathrm{CH}), 126.29(\mathrm{CH}), 126.56(\mathrm{CH}), 126.58(\mathrm{CH}), 126.88(\mathrm{CH}), 128.64$ $(\mathrm{CH}), 128.99(\mathrm{CH}), 129.03(\mathrm{C}), 130.25(\mathrm{C}), 130.32(\mathrm{C}), 130.39(\mathrm{C})$, 131.61 (C), 131.85 (C), 135.89 (C), $162.58(\mathrm{C}=\mathrm{O})$ ppm. HRMS (micrOTOF): calcd. for $\mathrm{C}_{24} \mathrm{H}_{18} \mathrm{NO}_{2}[\mathrm{M}+\mathrm{H}]^{+} 352.13375$; found 352.13321 .

Methyl 3-(Phenanthren-9-yl)-1 $\boldsymbol{H}$-dibenzo[e,g]indole-2-carboxylate (15): Compound 15 was prepared from $10(0.32 \mathrm{mmol}, 175 \mathrm{mg})$ according to the general procedure described above and with heating for $4 \mathrm{~h}(110 \mathrm{mg}, 52 \%)$. Column chromatography with diethyl ether/petroleum ether (1:3) afforded $\mathbf{1 5}$ as a white solid. M.p. 260.0-261.0 ${ }^{\circ} \mathrm{C}$ (from ethyl acetate/petroleum ether). ${ }^{1} \mathrm{H}$ NMR $\left(400 \mathrm{MHz}, \mathrm{CDCl}_{3}\right): \delta=3.55\left(\mathrm{~s}, 3 \mathrm{H}, \mathrm{OCH}_{3}\right), 7.00(\mathrm{t}, J=8 \mathrm{~Hz}, 1$ $\mathrm{H}, \mathrm{ArH}), 7.35-7.41$ (m, 3 H, ArH), 7.65-7.77 (m, 6 H, ArH), 7.91 (s, $1 \mathrm{H}, \mathrm{ArH}), 7.88$ (d, $J=8 \mathrm{~Hz}, 1 \mathrm{H}, \mathrm{ArH}), 8.24-8.26(\mathrm{~m}, 1 \mathrm{H}$, ArH), 8.61 (d, $J=8 \mathrm{~Hz}, 1 \mathrm{H}, \mathrm{ArH}), 8.70-8.73$ (m, $1 \mathrm{H}, \mathrm{ArH}), 8.86$ (d, $J=8.4 \mathrm{~Hz}, 2 \mathrm{H}, \mathrm{ArH}), 10.05$ (br. s, $1 \mathrm{H}, \mathrm{NH}$ ) ppm. ${ }^{13} \mathrm{C} \mathrm{NMR}$ $\left(100.6 \mathrm{MHz}, \mathrm{CDCl}_{3}\right): \delta=51.71\left(\mathrm{OCH}_{3}\right), 120.33(\mathrm{C}), 120.78(\mathrm{CH})$, $122.37(\mathrm{C}), 122.70(\mathrm{CH}), 122.81(\mathrm{CH}), 122.95(\mathrm{C}), 123.30(\mathrm{CH})$, $123.94(\mathrm{CH}), 124.04(\mathrm{CH}), 124.66(\mathrm{CH}), 124.84(\mathrm{C}), 126.53(\mathrm{CH})$, $126.62(\mathrm{CH}), 126.66(\mathrm{CH}), 126.72(\mathrm{CH}), 126.73(\mathrm{CH}), 126.78(\mathrm{CH})$, $127.06(\mathrm{CH}), 127.14(\mathrm{CH}), 127.85(\mathrm{C}), 128.50(\mathrm{CH}), 128.73(\mathrm{C})$, $128.89(\mathrm{CH}), 130.21(\mathrm{C}), 130.49$ (C), 130.63 (C), 131.92 (C), 131.98 (C), 132.39 (C), $162.14(\mathrm{C}=\mathrm{O})$ ppm. HRMS (micrOTOF): calcd. for $\mathrm{C}_{32} \mathrm{H}_{22} \mathrm{NO}_{4}[\mathrm{M}+\mathrm{H}]^{+}$452.16505; found 452.16451.

Methyl 9-Methyl-5,7-dihydro-4H-indeno[7,1-ef]indole-8-carboxylate (16): Compound 16 was prepared from $(Z)-5(0.27 \mathrm{mmol}, 100 \mathrm{mg})$ according to the general procedure described above and with heating for $4 \mathrm{~h}$. Crystallization (ethyl acetate/petroleum ether) gave $\mathbf{1 6}$ $(50 \mathrm{mg}, 70 \%)$ as a white solid. M.p. $240.0-241.0^{\circ} \mathrm{C}$ (from ethyl acetate/petroleum ether). ${ }^{1} \mathrm{H}$ NMR $\left(400 \mathrm{MHz}, \mathrm{CDCl}_{3}\right): \delta=3.00(\mathrm{~s}$, $\left.3 \mathrm{H}, \mathrm{CH}_{3}\right), 3.39-3.46\left(\mathrm{dd}, J=7.6 \mathrm{~Hz}, 4 \mathrm{H}, 2 \mathrm{CH}_{2}\right), 3.97$ (s, $3 \mathrm{H}$, $\left.\mathrm{OCH}_{3}\right), 7.21(\mathrm{~s}, 1 \mathrm{H}, \mathrm{ArH}), 7.31(\mathrm{~d}, J=7.2 \mathrm{~Hz}, 1 \mathrm{H}, \mathrm{ArH}), 7.56$ (t, $J=7.6 \mathrm{~Hz}, 1 \mathrm{H}, \mathrm{ArH}), 8.14$ (d, $J=8.0 \mathrm{~Hz}, 1 \mathrm{H}, \mathrm{ArH}), 8.97$ (br. $\mathrm{s}, 1 \mathrm{H}, \mathrm{NH}) \mathrm{ppm} .{ }^{13} \mathrm{C} \mathrm{NMR}\left(100.6 \mathrm{MHz}, \mathrm{CDCl}_{3}\right): \delta=12.77\left(\mathrm{CH}_{3}\right)$, $29.58\left(\mathrm{CH}_{2}\right), 31.01\left(\mathrm{CH}_{2}\right), 51.43\left(\mathrm{OCH}_{3}\right), 106.03(\mathrm{CH}), 118.32$ $(\mathrm{CH}), 119.05(\mathrm{CH}), 119.60(\mathrm{C}), 120.57$ (C), 127.95 (C), 128.37 $(\mathrm{CH}), 135.78(\mathrm{C}), 136.14(\mathrm{C}), 145.64(\mathrm{C}), 146.23(\mathrm{C}), 162.95(\mathrm{C}=\mathrm{O})$ ppm. $\mathrm{C}_{17} \mathrm{H}_{15} \mathrm{NO}_{2}$ (265.31): calcd. C 76.96, H 5.70, N 5.28; found C 76.55, H 5.36, N 4.99.

Methyl 3-(1,2-Dihydroacenaphthylen-5-yl)- $1 H$-indole-2-carboxylate (17) and Methyl 9-phenyl-5,7-dihydro-4H-indeno[7,1-ef]indole-8carboxylate (18): A mixture (4:1) of $\mathbf{1 7 / 1 8}$ was obtained by applying the general procedure described above to (Z)-6 $(0.35 \mathrm{mmol}$, $150 \mathrm{mg}$ ) and heating for $4 \mathrm{~h}(79 \mathrm{mg}, 65 \%)$. Column chromatography with diethyl ether/petroleum ether (1:3) afforded $\mathbf{1 7}$ as a white solid. M.p. $220.0-221.0^{\circ} \mathrm{C}$ (from ethyl acetate/petroleum ether). ${ }^{1} \mathrm{H} \mathrm{NMR}\left(400 \mathrm{MHz}, \mathrm{CDCl}_{3}\right): \delta=3.49$ (s, $\left.4 \mathrm{H}, 2 \mathrm{CH}_{2}\right), 3.65$ (s, $\left.3 \mathrm{H}, \mathrm{OCH}_{3}\right), 7.09$ (t, $\left.J=7.8 \mathrm{~Hz}, 1 \mathrm{H}, \mathrm{ArH}\right), 7.27-7.34(\mathrm{~m}, 3 \mathrm{H}$, ArH), 7.36-7.40 (m, 3 H, ArH), 7.49-7.54 (m, 2 H, ArH), 9.11 (br. s, $1 \mathrm{H}, \mathrm{NH}) \mathrm{ppm} .{ }^{13} \mathrm{C} \mathrm{NMR}\left(100.6 \mathrm{MHz}, \mathrm{CDCl}_{3}\right): \delta=30.21\left(\mathrm{CH}_{2}\right)$, $30.55\left(\mathrm{CH}_{2}\right), 51.70\left(\mathrm{OCH}_{3}\right), 111.66(\mathrm{CH}), 118.81(\mathrm{CH}), 119.02$ $(\mathrm{CH}), 120.64(\mathrm{CH}), 121.35(\mathrm{CH}), 122.08(\mathrm{C}), 122.27(\mathrm{CH}), 123.82$ (C), $125.79(\mathrm{CH}), 126.54(\mathrm{C}), 127.52(\mathrm{CH}), 128.83(\mathrm{C}), 130.19$ (CH), $130.94(\mathrm{C}), 135.77$ (C), 139.36 (C), 145.85 (C), 146.00 (C), $162.46(\mathrm{C}=\mathrm{O})$ ppm. HRMS (micrOTOF): calcd. for $\mathrm{C}_{22} \mathrm{H}_{18} \mathrm{NO}_{2}$ $[\mathrm{M}+\mathrm{H}]^{+}$328.13375; found 328.13321. Compound $\mathbf{1 8}$ was also isolated as white solid. M.p. $203.0-204.0^{\circ} \mathrm{C}$ (from ethyl acetate/ petroleum ether). ${ }^{1} \mathrm{H}$ NMR $\left(400 \mathrm{MHz}, \mathrm{CDCl}_{3}\right): \delta=3.43$ (s, $4 \mathrm{H}, 2$ $\mathrm{CH}_{2}$ ), 3.75 (s, $\left.3 \mathrm{H}, \mathrm{OCH}_{3}\right), 7.22-7.24(\mathrm{~m}, 3 \mathrm{H}, \mathrm{ArH}), 7.29$ (s, $1 \mathrm{H}$, 
ArH), 7.47-7.55 (m, $5 \mathrm{H}, \mathrm{ArH}), 9.21$ (br. s, $1 \mathrm{H}, \mathrm{NH}) \mathrm{ppm} .{ }^{13} \mathrm{C}$ NMR (100.6 MHz, $\left.\mathrm{CDCl}_{3}\right): \delta=29.63\left(\mathrm{CH}_{2}\right), 30.96\left(\mathrm{CH}_{2}\right), 51.49$ $\left(\mathrm{OCH}_{3}\right), 105.87(\mathrm{CH}), 118.63(\mathrm{CH}), 118.96(\mathrm{CH}), 119.28(\mathrm{C})$, $120.73(\mathrm{C}), 126.83(\mathrm{C}), 127.16(\mathrm{C}), 127.41(\mathrm{CH}), 128.01(\mathrm{CH})$, $128.16(\mathrm{CH}), 130.31(\mathrm{CH}), 135.68(\mathrm{C}), 135.72(\mathrm{C}), 135.96(\mathrm{C})$, $145.95(\mathrm{C}), 146.06(\mathrm{C}), 162.26(\mathrm{C}=\mathrm{O}) \mathrm{ppm}$. HRMS (micrOTOF): calcd. for $\mathrm{C}_{22} \mathrm{H}_{18} \mathrm{NO}_{4}[\mathrm{M}+\mathrm{H}]^{+} 328.13375$; found 328.133321 .

Methyl 1-Methyl-3H-benzo[e]indole-2-carboxylate (19): Compound 19 was prepared from $(Z)-7(0.29 \mathrm{mmol}, 112 \mathrm{mg})$ according to the general procedure described above and with heating for $6 \mathrm{~h}$. Column chromatography with diethyl ether/petroleum ether (1:4) afforded 19 (33.4 mg, 47\%) as a white solid. M.p. $212.0-213.0^{\circ} \mathrm{C}$ (from ethyl acetate/petroleum ether). ${ }^{1} \mathrm{H} \mathrm{NMR}\left(400 \mathrm{MHz}, \mathrm{CDCl}_{3}\right.$ ): $\delta=3.07\left(\mathrm{~s}, 3 \mathrm{H}, \mathrm{CH}_{3}\right), 3.99\left(\mathrm{~s}, 3 \mathrm{H}, \mathrm{OCH}_{3}\right), 7.45-7.49(\mathrm{~m}, 2 \mathrm{H}$, ArH), 7.60-7.64 (m, $1 \mathrm{H}, \mathrm{ArH}), 7.70(\mathrm{~d}, J=9.2 \mathrm{~Hz}, 1 \mathrm{H}, \mathrm{ArH})$, 7.91-7.93 (m, 1 H, ArH), 8.55 (d, $J=8.0 \mathrm{~Hz}, 1 \mathrm{H}, \mathrm{ArH}), 9.56$ (br. $\mathrm{s}, 1 \mathrm{H}, \mathrm{NH}) \mathrm{ppm} .{ }^{13} \mathrm{C} \mathrm{NMR}\left(100.6 \mathrm{MHz}, \mathrm{CDCl}_{3}\right): \delta=51.58$ $\left(\mathrm{OCH}_{3}\right), 112.92(\mathrm{CH}), 121.48(\mathrm{C}), 121.54(\mathrm{C}), 122.93(\mathrm{C}), 123.18$ $(\mathrm{CH}), 123.63(\mathrm{CH}), 126.61(\mathrm{CH}), 127.58(\mathrm{CH}), 129.14(\mathrm{CH}), 129.88$ (C), 130.20 (C), 133.58 (C), 162.86 (C=O) ppm. HRMS (EI): calcd. for $\mathrm{C}_{15} \mathrm{H}_{14} \mathrm{NO}_{2}[\mathrm{M}+\mathrm{H}]^{+}$240.10191; found 240.10180.

Methyl 3-(Naphthalen-1-yl)-1 $\boldsymbol{H}$-indole-2-carboxylate (20): Compound $\mathbf{2 0}$ was prepared from $(Z)-8(0.30 \mathrm{mmol}, 120 \mathrm{mg})$ according to the general procedure described above and with heating for $3 \mathrm{~h}$. Crystallization from diethyl ether/petroleum ether gave $\mathbf{2 0}(78 \mathrm{mg}$, $87 \%$ ) as a white solid. M.p. $168.0-169.0^{\circ} \mathrm{C}$ (from ethyl acetate/ petroleum ether). ${ }^{1} \mathrm{H} \mathrm{NMR}\left(400 \mathrm{MHz}, \mathrm{CDCl}_{3}\right): \delta=3.62$ (s, $3 \mathrm{H}$, $\left.\mathrm{OCH}_{3}\right), 7.10(\mathrm{t}, J=7.6 \mathrm{~Hz}, 1 \mathrm{H}, \mathrm{ArH}), 7.27-7.42(\mathrm{~m}, 3 \mathrm{H}, \mathrm{ArH})$, 7.47-7.61 (m, $4 \mathrm{H}, \mathrm{ArH}), 7.66$ (d, $J=8.4 \mathrm{~Hz}, 1 \mathrm{H}, \mathrm{ArH}), 7.94$ (d, $J=8.0 \mathrm{~Hz}, 2 \mathrm{H}, \mathrm{ArH}$ ), 9.32 (br. s, $1 \mathrm{H}, \mathrm{NH}) \mathrm{ppm} .{ }^{13} \mathrm{C} \mathrm{NMR}$ $\left(100.6 \mathrm{MHz}, \mathrm{CDCl}_{3}\right): \delta=51.73\left(\mathrm{OCH}_{3}\right), 111.76(\mathrm{CH}), 120.80$ $(\mathrm{CH}), 122.08(\mathrm{CH}), 122.15(\mathrm{C}), 124.12(\mathrm{C}), 125.15(\mathrm{CH}), 125.55$ $(\mathrm{CH}), 125.65(\mathrm{CH}), 125.84(\mathrm{CH}), 126.23(\mathrm{CH}), 127.88(\mathrm{CH}), 128.12$ $(\mathrm{CH}), 128.45(\mathrm{CH}), 128.93(\mathrm{C}), 131.53(\mathrm{C}), 132.69(\mathrm{C}), 133.56(\mathrm{C})$, $135.77(\mathrm{C}), 162.52(\mathrm{C}=\mathrm{O}) \mathrm{ppm}$. HRMS (micrOTOF): calcd. for $\mathrm{C}_{20} \mathrm{H}_{16} \mathrm{NO}_{4}[\mathrm{M}+\mathrm{H}]^{+}$302.11810; found 302.11756.

Methyl 1-(Naphthalen-1-yl)-3H-benzo[e]indole-2-carboxylate (21): Compound 21 was prepared from $12(0.30 \mathrm{mmol}, 120 \mathrm{mg})$ according to the general procedure described above and with heating for $3 \mathrm{~h}$. Crystallization from diethyl ether/petroleum ether gave 21 (144 mg, 86\%) as a white solid. M.p. $194.0-195.0^{\circ} \mathrm{C}$ (from ethyl acetate/petroleum ether). ${ }^{1} \mathrm{H}$ NMR $\left(400 \mathrm{MHz}, \mathrm{CDCl}_{3}\right): \delta=3.56(\mathrm{~s}$, $\left.3 \mathrm{H}, \mathrm{OCH}_{3}\right), 7.04(\mathrm{t}, J=7.6 \mathrm{~Hz}, 1 \mathrm{H}, \mathrm{ArH}), 7.14(\mathrm{~d}, J=8.0 \mathrm{~Hz}$, $1 \mathrm{H}, \mathrm{ArH}), 7.25-7.32(\mathrm{~m}, 2 \mathrm{H}, \mathrm{ArH}), 7.48(\mathrm{t}, J=7.2 \mathrm{~Hz}, 1 \mathrm{H}$, ArH), 7.56-7.67 (m, $4 \mathrm{H}, \mathrm{ArH}), 7.77$ (d, $J=8.8 \mathrm{~Hz}, 1 \mathrm{H}, \mathrm{ArH})$, $7.85(\mathrm{~d}, J=8.0 \mathrm{~Hz}, 1 \mathrm{H}, \operatorname{ArH}), 7.98(\mathrm{~d}, J=8.4 \mathrm{~Hz}, 1 \mathrm{H}, \mathrm{ArH})$, $8.02(\mathrm{~d}, J=7.6 \mathrm{~Hz}, 1 \mathrm{H}, \mathrm{ArH}), 9.78$ (br. s, $1 \mathrm{H}, \mathrm{NH}$ ) ppm. ${ }^{13} \mathrm{C}$ NMR $\left(100.6 \mathrm{MHz}, \mathrm{CDCl}_{3}\right): \delta=51.61\left(\mathrm{OCH}_{3}\right), 112.91(\mathrm{CH})$, $122.04(\mathrm{C}), 122.88(\mathrm{C}), 123.03(\mathrm{CH}), 123.88(\mathrm{CH}), 123.95(\mathrm{C})$, $125.52(\mathrm{CH}), 125.74(\mathrm{CH}), 126.03(\mathrm{CH}), 126.47(\mathrm{CH}), 127.85(\mathrm{CH})$, $128.01(\mathrm{CH}), 128.13(\mathrm{CH}), 128.75(\mathrm{CH}), 129.10(\mathrm{C}), 129.93(\mathrm{C})$, 132.87 (C), 133.49 (C), 133.61 (C), 133.72 (C), 162.31 (C=O) ppm. $\mathrm{C}_{24} \mathrm{H}_{17} \mathrm{NO}_{2}$ (351.38): calcd. C 82.03, $\mathrm{H} 4.88, \mathrm{~N} \mathrm{3.99}$; found $\mathrm{C}$ 81.64, H 4.46, N 4.29.

Spectroscopic Measurements: All solutions were prepared by using spectroscopy-grade solvents. Absorption spectra were recorded with a Shimadzu UV-3101PC UV/Vis/NIR spectrophotometer. Fluorescence measurements were performed with a Spex Fluorolog 3 spectrofluorimeter, equipped with double monochromators in both excitation and emission and a temperature-controlled cuvette holder. Fluorescence spectra were corrected for the instrumental response of the system.
Fluorescence Quantum Yields: For fluorescence quantum yield determinations, the solutions were bubbled with ultrapure nitrogen for $40 \mathrm{~min}$ before measurement. The fluorescence quantum yields $\left(\Phi_{\mathrm{S}}\right)$ were determined by the standard method [Equation (1)]. ${ }^{[21,22]}$ 9,10 -Diphenylanthracene in ethanol $\left(\Phi_{\mathrm{r}}=0.95^{[10]}\right)$ was the reference.

$\Phi_{\mathrm{s}}=\frac{A_{\mathrm{r}} F_{\mathrm{S}} n_{\mathrm{s}}^{2}}{A_{\mathrm{s}} F_{\mathrm{r}} n_{\mathrm{r}}^{2}} \Phi_{\mathrm{r}}$

where $A$ is the absorbance at the excitation wavelength, $F$ the integrated emission area and $n$ the refraction index of the solvents used. Subscripts refer to the reference (r) or sample (s) compound.

Fluorescence and UV/Vis Absorption Titrations: Stock solutions $\left(5 \times 10^{-6} \mathrm{M}\right)$ were prepared by using spectroscopy-grade acetonitrile. Solutions of tetrabutylammonium fluoride, tetrabutylammonium chloride, tetrabutylammonium bromide, tetrabutylammonium hydrogen sulfate and tetrabutylammonium acetate were prepared at $1 \times 10^{-2} \mathrm{M}$. The solution containing the fluorescent compound ( $2 \mathrm{~mL}$ of stock solution) was placed in a quartz cell $(10.0 \mathrm{~mm}$ width), and the tetrabutylammonium salt solution was introduced in an incremental fashion. The corresponding absorption and fluorescence spectra were recorded at $25^{\circ} \mathrm{C}$ and were corrected for dilution.

Supporting Information (see footnote on the first page of this article): Several figures including the emission observed from a solution of $\mathbf{1 3}$ and $\mathbf{1 5}$ and of $\mathbf{1 3}+\mathrm{F}^{-}$and $\mathbf{1 5}+\mathrm{F}^{-}$in acetonitrile, under irradiation with $340 \mathrm{~nm}$ light; the normalised absorption of $\mathbf{1 3}$ and $\mathbf{1 5}\left(5 \times 10^{-6} \mathrm{M}\right.$ in acetonitrile) and excitation spectrum of $\mathbf{1 3}$ and $\mathbf{1 5}$ +500 equiv. of $\mathrm{F}^{-}$; the fluorescence emission spectra $\left(\lambda_{\mathrm{ex}}=335 \mathrm{~nm}\right)$ of $15\left(5 \times 10^{-6} \mathrm{M}\right.$ in acetonitrile $)$ in the presence of different amounts of $\mathrm{OH}^{-}(0,5,10,15,20,25,30,40,50,60,70,80$ and 90 equiv. $)$ and the absorption of $15\left(5 \times 10^{-6} \mathrm{M}\right.$ in acetonitrile $)$ in the absence and presence of $\mathrm{OH}^{-}$(90 equiv.).

\section{Acknowledgments}

We thank the Foundation for the Science and Technology (FCT) Portugal and FEDER (Fundo Europeu de Desenvolvimento Regional) for financial support of the Centro de Física (CFUM) and the Centro de Química (CQ-UM) and through Project PTDC/QUI/ $81238 / 2006$. The Bruker Avance II 400 NMR spectrometer is part of the National NMR Network and was acquired with funds from FCT and FEDER. G. P. acknowledges the FCT for a Ph.D. grant (SFRH/BD/38766/2007).

[1] a) A. S. Abreu, N. O. Silva, P. M. T. Ferreira, M.-J. R. P. Queiroz, M. Venanzi, Eur. J. Org. Chem. 2003, 4792-4796; b) M.J. R. P. Queiroz, E. M. S. Castanheira, M. S. D. Carvalho, A. S. Abreu, P. M. T. Ferreira, H. Karadeniz, A. Erdem, Tetrahedron 2008, 64, 382-391; c) M.-J. R. P. Queiroz, A. S. Abreu, M. S. D. Carvalho, P. M. T. Ferreira, N. Nazareth, M. S.-J. Nascimento, Bioorg. Med. Chem. 2008, 16, 5584-5589.

[2] G. Pereira, A. S. Abreu, E. M. S. Castanheira, P. J. G. Coutinho, P. M. T. Ferreira, M.-J. R. P. Queiroz, Eur. J. Org. Chem. 2009, 3906-3916.

[3] a) Z. Xu, S. K. Kim, S. J. Han, C. Lee, G. Kociok-Kohn, T. D. James, J. Yoon, Eur. J. Org. Chem. 2009, 3058-3065; b) J. Y. Kwon, Y. J. Jang, S. K. Kim, K.-H. Lee, J. S. Kim, J. Yoon, J. Org. Chem. 2004, 69, 5155-5157; c) X. Peng, Y. Wu, J. Fang, M. Tian, K. Han, J. Org. Chem. 2005, 70, 10524-10531; d) S. K. Kim, J. H. Bok, R. A. Bartsch, J. Y. Lee, J. S. Kim, Org. 
Lett. 2005, 7, 4839-4842; e) D. Esteban-Gómez, L. Fabrizzi, M. Licchelli, J. Org. Chem. 2005, 70, 5717-5720.

[4] a) E. D. Kharasch, Clin. Pharm. Ther. 2008, 84, 158-162; b) M. Laisalmi, H. Kokki, A. Soikkeli, H. Markkanen, A. YliHankala, P. Rosenberg, L. Lindgren, Acta Anaesthesiol. Scand. 2006, 50, 982-987; c) G. Walldbott, Clin. Toxicol. 1981, 18 , 531-541; d) S. P. Dubey, K. Gopal, J. L. Besillon, J. Environ. Biol. 2009, 30, 327-337.

[5] C. Lodeiro, F. Pina, Coord. Chem. Rev. 2009, 253, 1353-1383.

[6] a) A. G. Brown, T. C. Smale, J. Chem. Soc. C 1969, 1489-1490; b) M. Yamada, K. Nakao, T. Fukui, K. Nunami, Tetrahedron 1996, 52, 5751-5764; c) P. M. T. Ferreira, L. S. Monteiro, M.J. R. P. Queiroz, G. Pereira, Amino Acids 2009, 36, 429-436.

[7] G. B. Jones, J. E. Mathews, Tetrahedron 1997, 53, 14599-14614.

[8] J. V. Morris, M. A. Mahaney, J. R. Huber, J. Phys. Chem. 1976, 80, 969-974.

[9] D. Creed, Photochem. Photobiol. 1984, 39, 537-562.

[10] B. Albinsson, M. Kubista, B. Nordén, E. W. Thulstrup, J. Phys. Chem. 1989, 93, 6646-6654.

[11] H. Lippert, H.-H. Ritze, I. V. Hertel, W. Radloff, Chem. Phys. Lett. 2004, 398, 526-531.

[12] I. Tatischeff, R. Klein, Photochem. Photobiol. 1975, 22, 221229.
[13] N. J. Turro, Modern Molecular Photochemistry, Benjamin/ Cummings Pub., Menlo Park (California), 1978.

[14] S. Selvi, S.-C. Pu, Y.-M. Cheng, J.-M. Fang, P.-T. Chou, J. Org. Chem. 2004, 69, 6674-6678.

[15] M. Boiocchi, L. Boca, D. Esteban-Gómez, L. Fabbrizzi, M. Licchelli, E. Monzani, Chem. Eur. J. 2005, 11,3097-3104; J. V. Ros-Lis, R. Martínez-Máñez, F. Sancenón, J. Soto, K. Rurack, H. Weißhoff, Eur. J. Org. Chem. 2007, 2449-2458.

[16] C.-I. Lin, S. Selvi, J.-M. Fang, P.-T. Chou, C.-H. Lai, Y.-M. Cheng, J. Org. Chem. 2007, 72, 3537-3542.

[17] H.-T. Yu, W. J. Colucci, M. L. McLaughlin, M. D. Barkley, J. Am. Chem. Soc. 1992, 114, 8449-8454.

[18] N. O. Silva, A. S. Abreu, P. M. T. Ferreira, L. S. Monteiro, M.J. R. P. Queiroz, Eur. J. Org. Chem. 2002, 2524-2528.

[19] N. O. Silva, A. S. Abreu, P. M. T. Ferreira, M.-J. R. P. Queiroz, Tetrahedron Lett. 2003, 44, 3377-3379.

[20] A. S. Abreu, P. M. T. Ferreira, L. S. Monteiro, M.-J. R. P. Queiroz, I. C. F. R. Ferreira, R. C. Calhelha, L. M. Estevinho, Tetrahedron 2004, 60, 11821-11828.

[21] J. N. Demas, G. A. Crosby, J. Phys. Chem. 1971, 75, 991-1024.

[22] S. Fery-Forgues, D. Lavabre, J. Chem. Educ. 1999, 76, 1260 1264.

Received: July 3, 2009

Published Online: December 1, 2009 